\title{
From Caesar to Charlemagne
}

\section{The Tradition of Trojan Origins}

Yavuz, N. Kvlcm

Published in:

Medieval History Journal

DOI:

$10.1177 / 0971945818775372$

Publication date:

2018

Document version

Peer reviewed version

Document license:

CC BY-NC

Citation for published version (APA):

Yavuz, N. K. (2018). From Caesar to Charlemagne: The Tradition of Trojan Origins. Medieval History Journal, 21(2), 251-90. https://doi.org/10.1177/0971945818775372 


\title{
From Caesar to Charlemagne: The Tradition of Trojan Origins
}

\author{
N. Kivilcim Yavuz
}

The Trojan War, which is traditionally considered to have occurred in the twelfth century BCE, has been one of the most exploited subjects of European culture and history. Not only did it provide some of the most important literary motifs for ancient Greek and Roman culture, but it also played a role in the genesis of the nations of early medieval Europe. The Trojans had an afterlife that connected them to multitudes of subsequent peoples. This study examines the story of the Trojan origins of the Franks from its inception during the Merovingian period to its development under the Carolingians. Considering both textual and manuscript evidence, it discusses the dissemination of the origin story as well as its association with Charlemagne.

Acknowledgements: I would like to express my thanks to the staff in the following libraries: Biblioteca Apostolica Vaticana, Vatican City; Bibliothèque nationale de France, Paris, France; Österreichische Nationalbibliothek, Vienna, Austria; Universiteitsbibliotheek, Leiden, the Netherlands; British Library, London, the UK; Hill Museum \& Manuscript Library, Saint John’s Abbey and University, Collegeville, MN, the USA.

* Marie Skłodowska-Curie Fellow, Arnamagnæan Institute, University of Copenhagen, Njalsgade i36, 2300, Copenhagen, Denmark.

E-mail: nky@hum.ku.dk 
After the sack of Troy by the Greeks in c. II84 BCE, the Trojan hero Aeneas, the son of Venus, was said to have fled with his father Anchises and son Ascanius (or Iulus) to Italy, where

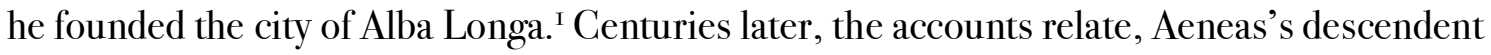
Romulus then founded the city of Rome. As a consequence, there were many traditions, too well known to need further elaboration here, relating to the Trojan origins of the Romans. ${ }^{2}$ For example, Julius Caesar's (c. IOO-44 BCE) own gentilic name Julius was taken to refer to his direct descent from Iulus, the son of Aeneas, and thus from Venus herself. ${ }^{3}$ Indeed, as Badian states, 'the origin of the Iulii was shrouded in myth deriving their ancestry from Aeneas and Venus long before the age of Caesar'. ${ }^{4}$ With Julius Caesar tracing his ancestry all the way back to the Trojan exile Aeneas, there was a continued imperial interest in Troy. ${ }^{5}$

Caesar's adopted son Augustus (63 BCE - I4 CE) then made much of this connection to Troy in his creation of the Roman Empire, in the course of which the poet Virgil penned the definitive Roman epic, the Aeneid (c. I9 BCE), the story of Aeneas's travels to Italy. ${ }^{6}$ Several works from this period such as Sallust's Bellum Catilinae (c. 4I-4O BCE) and Livy's Ab urbe condita libri (c. 25 BCE) not only included the story of the Trojan origins of the Romans but also, like the Aeneid, became very influential in the later centuries. ${ }^{7}$ But the Romans were not the only ones to be linked with the Trojans; the Venetians, the Patavians and the Arverni, to name a few, all got associated one way or another with the Trojans in classical accounts. The Trojan migrants thus had an afterlife that connected them to multitudes of subsequent peoples. After the fall of the Western Roman Empire in the fifth century, through different written accounts, stories of Trojan origins connected most of the European peoples to Troy. During the Middle Ages, the Franks along with the Macedonians, the Turks, the British, the Normans, the Danes and even the Icelanders were traced back to migrant Trojans. Among the peoples who claim descent from Troy during the early Middle Ages, the case of Franks is perhaps the most significant as the origin story was appropriated and tailored to their needs in such a manner that it continued to find passionate advocates well into the eighteenth century. ${ }^{8}$

\section{Franks as Trojans: The Origins of the Story}

The earliest written accounts of the Trojan origins of the Franks are found in an anonymous seventh-century historiographical compilation commonly referred to as the

\footnotetext{
${ }^{\mathrm{I}}$ In this study available translations from Latin were utilised; in most cases, they were revised for the sake of overall consistency.

${ }^{2}$ See especially Perret, Origines; Poucet, Origines de Rome; Cornell, Beginnings of Rome: 48-80; Gruen, Culture and National Identity: 6-5.

${ }^{3}$ Weinstock, Divus Julius: 4-I8.

${ }^{4}$ Badian, 'From the Iulii to Caesar': II.

${ }^{5}$ Yavuz, 'Looking Back at the Fifth Century'. See also Rose, Archaeology of Greek and Roman Troy: especially 2I7-7I and Sage, 'Roman Visitors to Ilium'.

${ }^{6}$ See Virgil, Aeneis.

${ }^{7}$ See Livy, History of Rome; Sallust, War with Catiline.

${ }^{8}$ For the general framework of origin stories and ethnicity, see especially Geary, 'Ethnicity as a Situational Construct'; Wolfram, 'Origo et Religio'; Pohl, 'Conceptions of Ethnicity'; Pohl, 'Historiography and Identity'.
} 
Chronicle of Fredegar in modern scholarship. ${ }^{9}$ Very little can be securely said about either the author or the contents of the 'original' Chronicle of Fredegar. ${ }^{\mathrm{IO}}$ In its current state, it includes two accounts of the Trojan origins not only of the Franks but also of the Romans, the Macedonians and the Turks. One account is found in a section attributed to St Jerome (347420 ) and the other in a section attributed to Gregory of Tours (c. 538-594). Albeit rather briefly, both accounts detail the journey of the Trojans in the aftermath of the Trojan War, their encounters with other peoples during their journey and their eventual settlement(s) in Europe.

The Chronicle of Fredegar is a significant piece of work for more reasons than one. In modern scholarship, it has been regarded as 'the only source of any significance for much of the period it covers' and has been valued for its contribution to the 'historiographical lacuna

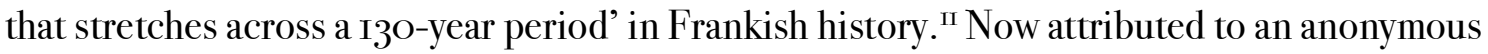
author conventionally named Fredegar, the original compilation is thought to have been completed around 66o. ${ }^{\text {I2 }}$ The contents of the work, laid out in four books in the modern edition, consist of a series of selected excerpts from previous works, which are organised in a roughly chronological order that runs from the creation of the world to the year $642 .{ }^{13}$ Thus, it brings together information in the manner of a history book that begins with the creation of the world and ends with the contemporary events of the author's times. The text comes to an end with events of 642 but there are several reasons to think that the work began circulating in an unfinished state. ${ }^{14}$ Even though sections of the Chronicle of Fredegar are presented as excerpts belonging to other works, parts of the text have been reworked to accommodate several omissions and additions. ${ }^{15}$

The Chronicle of Fredegar has been consistently described as a 'universal chronicle'. ${ }^{6}$ It is evident from the surviving manuscripts, however, that the work is not introduced to the

\footnotetext{
${ }^{9}$ See Fredegar, Chronicarum quae dicuntur Fredegarï.

${ }^{10}$ See especially Collins, Fredegar-Chroniken.

"Wallace-Hadrill, 'Introduction': v and Collins, Fredegar: 4 respectively.

${ }^{12}$ For the dating, see Collins, Fredegar-Chroniken: $25^{-27}$. The witnesses to this seventh-century compilation are those manuscripts that are categorised as Classes I, 2 and 3 in Krusch's edition. See Fredegar, Chronicarum quae dicuntur Fredegarï: 9-16. For further information on the classification of manuscripts, see also Krusch, 'Chronicae des sogenannten Fredegar'.

${ }^{13}$ See Collins, Fredegar-Chroniken: 27-38.

${ }^{14}$ For example, the first section, which contains the Liber generationis, also includes a series of lists that duplicate some of the information already found in the Liber generationis but provide different regnal dates. Considering the reworkings that went into the second and third sections, it seems likely that the editing of the first section was still on-going when the work began circulating. The final section also seems incomplete, as there are references to events that happened after $64_{2}$ in the earlier parts of the section that are not included later in the text. These references are also part of the reasoning behind the dating of the compilation. It also seems highly probable that a reworking of the Chronicon of Isidore of Seville was intended to be a part of the compilation. See Isidore of Seville, Isidori Hispalensis Chronica. For the use of Isidore's Chronicon, see Collins, Fredegar-Chroniken: 35-38.

${ }^{15}$ The sources for most of these additions, including both accounts of the story of Trojan origins, remain unidentified. The last part of the work, which covers the years from $5^{8} 4$ to 642 , is often thought to have been composed ex nihilo by the 'original' compiler(s), probably as a continuation of the material already collected.

${ }^{16}$ See, for example, Goffart, 'Fredegar Problem Reconsidered': 2o6; also Wood, 'Universal Chronicles'.
} 
audience as an 'original' historiographical work per se, nor it is offered as a brand new take on past and contemporary historical events. Not only is the whole work not attributed to one specific author but there also is no general title given to the work; it is merely presented as a collection of excerpts from other, older, more authoritative works. ${ }^{17}$ As will be clear from the discussion below, this point, which always has been downplayed in modern scholarship, is crucial especially when considering both the transmission and the reception of the story of the Trojan origins. Even though there is a lot of controversy over how the work was originally structured, one thing is clear: it was divided into sections. ${ }^{18}$ This is also how the work is presented in its famous prologue: a series of selections from other works, followed by one final 'original' section. ${ }^{19}$

The passages where the Franks are connected to the Trojans in the Chronicle of Fredegar are found in sections clearly marked as 'excerpts' from the chronicles of Jerome and Gregory: Scarpsum de Cronica Hieronimi and Scarpsum de Cronica Gregorï. The Scarpsum de Cronica Hieronimi, or Book II in the modern edition, is a reworking of a version of the Latin translation and continuation of the Greek Chronici canones of Eusebius of Caesarea by Jerome (also known as the Eusebius-Jerome Chronicle) and its continuation by Hydatius as well as a series of stories about the fifth and sixth centuries, sources of which remain unidentified. ${ }^{20}$ The Scarpsum de Cronica Gregorï, or Book III, is a reworking of an abridged six-book version of Gregory of Tours's Decem libri historiarum. ${ }^{2 \mathrm{I}}$

Many scholars dismiss the possibility of the existence of the story of the Trojan origins of the Franks prior to its appearance in the Chronicle of Fredegar and thus claim that it could not have existed before the second half of the seventh century. ${ }^{22}$ For example, Anton finds the conception of the story 'hardly conceivable' before the seventh century, and Asher calls the emergence of the story 'almost certainly an erudite invention'. ${ }^{23}$ Even more recently, Ghosh argues that there is 'no actual evidence for a Trojan myth connected specifically to the Franks before Fredegar' and that 'there is no warrant for believing in the existence of any ancient tradition (written or oral) that suggests a Trojan origin for the Franks and is the source for Fredegar'. ${ }^{24}$

Luiselli, among others, however, finds this idea of a 'seventh-century invention' not at all convincing. ${ }^{25}$ By the time the Chronicle of Fredegar was written, not only was the story of Troy in its various forms widespread but the historicity of the Trojan War also was well established. ${ }^{26}$ In different contexts and for different reasons, several classical and late antique

\footnotetext{
${ }^{\text {r7 }}$ The modern attribution to a 'Fredegar' as the author dates back to the sixteenth century.

${ }^{18}$ See Collins, Fredegar-Chroniken: $3^{8-46 .}$.

${ }^{19}$ Fredegar, Chronicarum quae dicuntur Fredegarï: 123.

${ }^{20}$ See Jerome, Eusebius Caesariensis: Werke 7; Hydatius, 'Chronicle' of Hydatius.

${ }^{21}$ See Gregory of Tours, Gregorii Turonensis opera: Libri historiarum X. For the translation, see History of the Franks. There is no edition of the abridged six-book version; see Reimitz, History, Frankish Identity: especially I33-40.

${ }^{22}$ First elaborated in I929 in Faral, 'Comment s'est formée la légende del'origine troyenne des Francs', with many supporters since then.

${ }^{23}$ Anton, 'Troja-Herkunft': 30; Asher, 'Idea of a Trojan Origin': 9 .

${ }^{24}$ Ghosh, Writing the Barbarian Past: Io6, Io8.

${ }^{25}$ Luiselli, 'Mito dell'origine troiana': especially 89.

${ }^{26}$ See Yavuz, 'Transmission and Adaptation': I2-28.
} 
accounts attest that the Trojans migrated to different parts of Europe following the war, and some of these accounts further mention that Trojan migrants settled in Gaul, which eventually became Frankish territory. One of the better-known attestations belongs to Ammianus Marcellinus (c. 330-39I). When narrating the undertakings of the emperor in Gaul, Ammianus cites a now lost work by Timagenes reporting that when Troy was sacked by the Greeks, some Trojans who managed to escape fled to Gaul:

Ambigentes super origine prima Gallorum scriptores veteres notitiam reliquere negotii semiplenam, sed postea Timagenes [...] haec quae diu sunt ignorata collegit ex multiplicibus libris, cuius fidem secuti [...] obscuritate dimota eadem distincte docebimus et aperte [...] aiunt quidam paucos post excidium Troiae fugitantes Graecos ubique dispersos loca haec occupasse tunc vacua.

The ancient writers, in doubt as to the earliest origin of the Gauls, have left an incomplete account of the matter, but later Timagenes [...] collected out of various books these facts that were long unknown, which, following his authority and avoiding any obscurity, I shall state clearly and plainly. [...] Some assert that after the destruction of Troy a few of those who fled from the Greeks and were scattered everywhere occupied those regions [in Gaul], which were then deserted. ${ }^{27}$

Even though Trojan ancestry had become a topic of interest due to the claims by the Romans and until this time it was almost exclusively found in Roman sources to promote their Trojan origins, itis important to note that it was not only the Romans who were associated with the Trojans. Ewig, for example, finds that the statement of Ammianus resonates with what is found in the Chronicle of Fredegar. ${ }^{28}$ Accordingly, different peoples living in the region of Gaul and the wider Frankish territory had been associated with the Trojans much earlier than the seventh century.

Based on this connection with Gaul, Wallace-Hadrill asserts that the story of Trojan origins must have been diffused earlier, well before Fredegar's time: ${ }^{29}$

we have to remember that, in one form or another, tales of Troy were familiar to educated Gauls of the Later Empire. [...] It must [...] be borne in mind that the Gaulish atmosphere was already impregnated with Trojana by the time Franks arrived, so that we might expect a Frankish-Trojan connection too at any time from the fifth century. ${ }^{30}$

\footnotetext{
${ }^{27}$ Ammianus Marcellinus, History: vol. I: I76-79 (XV.9.2, XV.9.5). Ghosh (Writing the Barbarian Past: Io6) erroneously translates 'a few Greeks, fleeing after the fall of Troy'.

${ }^{28}$ Ewig, 'Mythe troyen': 84I.

${ }^{29}$ Wallace-Hadrill, 'Fredegar and the History of France': especially $53^{6-38}$. Also see Wallace-Hadrill, 'Introduction': xii.

${ }^{30}$ Wallace-Hadrill, 'Fredegar and the History of France': 536.
} 
Also emphasising that 'in late antique Gaul Trojan origin legends for cities and tribes had been common', Innes further states that the tradition of the Trojan origins of the Franks 'is thus likely to have arisen in the decades after their conquest of Gaul, or perhaps earlier as part of an alliance between a Frankish group and Roman leaders'. ${ }^{3}$ Similarly, underlining that Franks had interactions with the Romans since the third century, Barlow argues for 'an early stage prior to their [the Franks'] Christianisation, some time between the late third and mid fourth centuries'. ${ }^{2}$ Wood, on the other hand, suggests that 'there may [...] be some historical significance in the discovery of Frankish origins in the history of Troy'. ${ }^{33}$ In line with this view, I have argued that the story might have originated during the reign of Frankish king Childeric (r. 457-48I/82), right at the beginning of the establishment of the Merovingian dynasty as a result of connections of the Franks with the Eastern Roman Empire. ${ }^{34}$

Indeed, there also is no record of any other, contemporary or earlier, origo gentis story for the Franks. Earlier texts either mention the Franks in passing or when they deal with them more comprehensively, as in the case of Gregory's Historiae, they do not go into details about their origins or their distant past. ${ }^{35}$ What the evidence shows, however, is that there was a long tradition before the Chronicle of Fredegar was put down into writing, and this strongly suggests that the story of the Trojan origins of the Franks could have been already in circulation at this time. Nevertheless, irrespective of whether the story existed beforehand in oral culture or otherwise, or these two accounts were fabricated by one Fredegar, the Chronicle of Fredegar is a crucial milestone both for Frankish historiography and for the development of the Trojan narrative. This is not only because the first written accounts of the story of Trojan origins of the Franks come from this period but also because of how the narrative develops in the eighth century.

\section{The Turning Point: The Eighth Century}

During the eighth century, as the Merovingian dynasty (450-75I) gradually lost influence and the Carolingian dynasty $\left(75^{\mathrm{I}-987}\right)$ consolidated its power over Francia, the Trojan narrative received a different kind of attention. Between the 720 and $77 \mathrm{Os}$, within around a 50-year period, different versions of the story of the Trojan origins of the Franks began circulating in the Frankish realm. The first of such work to contain the story is the Liber historiae Francorum (hereafter LHF) ['The Book of the History of Franks'], which almost

\footnotetext{
${ }^{3 \mathrm{I}}$ Innes, 'Teutons or Trojans?': 248.

$3^{2}$ Barlow, 'Gregory of Tours and the Myth': 9o.

${ }^{33}$ Wood, 'Defining the Franks': 53. Wood, Merovingian Kingdoms: 35, suggests another theory for the late appearance of the story and argues that these accounts 'may have been written in response to the origin legends of the Goths, which had been developed by Cassiodorus and preserved by Jordanes'.

34 Yavuz, 'Looking Back at the Fifth Century'.

35 Whether or not Gregory of Tours, writing at the end of the sixth century, knew the story has been a matter of debate. See, for example, Barlow, 'Gregory of Tours and the Myth': 86; Gerberding, Rise of the Carolingians: I3; James, 'Gregory of Tours'; Reimitz, History, Frankish Identity: 86; Wood, 'Defining the Franks': 53; Wood, Merovingian Kingdoms: 35; Murray, From Roman to Merovingian Gaul: 590; Yavuz, 'Looking Back at the Fifth Century'.
} 
immediately became one of the most influential works on the history of the Franks. ${ }^{36}$ Now dated to 727 , neither its place of production nor its author is known. ${ }^{37}$ This anonymous work shortlyif not immediately-began circulating under the name of Gregory of Tours not least because, much like the Scarpsum de Cronica Gregorï that is part of the Chronicle of Fredegar, it heavily depends on Gregory's Historiae. ${ }^{3}$ Indeed, four out of the six earliest surviving manuscript witnesses of the work, dating from the late eighth to the early ninth centuries, bear the name of Gregory in their incipits, with the other two calling the work 'liber historiae'. 39

Even though information about the Trojan origins of the Franks is incorporated into Gregory's account in both rewritings, the author of the $L H F$ is thought not to have known the Chronicle of Fredegar. The version of the story included in the LHF contains different details from those found in the Chronicle of Fredegar, and the three versions only agree in the broadest outline. There are no identified borrowings from the Chronicle of Fredegar in the remainder of the $L H F$ either. Thus, it has been agreed that the story of the Trojan origins of the Franks in the $L H F$ is independent of both accounts found in the Chronicle of Fredegar. That the two earliest works to include the story were not dependent on each other also has led to arguments about the existence of the story either prior to its appearance in the Chronicle of Fredegar or about its circulation in different forms in addition to the Chronicle of Fredegar. Ewig firmly states that 'les deux versions de Frédégaire et celle du Liber représentent deux traditions distinctes de l'Origo Francorum, qui reposent toutes deux sur un fondement gallo-romain'. ${ }^{\circ}$ Yet, these so-called two distinct traditions that contain different versions of the story were circulated, read and used side by side throughout the Frankish realm from the beginning of the eighth century onwards.

Very soon after the completion of the $L H F$, the Trojan ancestry of the Franks was included in the Aethici philosophi Scythae Cosmographia ['The Cosmography of the Philosopher Aethicus the Scythian']. ${ }^{4}$ This work is presented as a series of excerpts from the writings of a philosopher Aethicus, and the author claims to be Hieronymus, that is, St Jerome himself. It has been established that the work could not have been written by or at the time of Jerome, and it is now dated to the beginning of the second quarter of the eighth century, to $730 .^{42}$ That the work was not in fact composed by Jerome is mainly demonstrated by the use

\footnotetext{
${ }^{36}$ See $L H F$, edited by Krusch and translated into English by Bachrach.

${ }^{37}$ The dating is due to a reference to the sixth year of Theuderic IV (r. 72I-737) in the very last sentence of the work in Chapter 53. See LHF: 217; Gerberding, Rise of the Carolingians: 144-45. For authorship and previous scholarship, see Gerberding, Rise of the Carolingians: ${ }_{4}^{4} 6-7^{2}$. For arguments for female authorship, see Nelson, 'Gender and Genre in Women Historians'; McKitterick, 'Women and Literacy'.

$3^{8}$ As in the case of the Chronicle of Fredegar, this reworking is also based on an abridged six-book version of Gregory's Historiae.

${ }^{39}$ In chronological order, Paris, BNF, Lat. 7906 (Part III) + Paris, BNF, Lat. 5 OI8 (Part II); Vatican City, BAV, Pal. Lat. 966; Vatican City, BAV, Ott. Lat. 663 and Leiden, UBL, VLO 86. See Yavuz, 'Transmission and Adaptation': especially ${ }_{5}{ }^{6-57}$.

${ }^{40}$ Ewig, 'Mythe troyen': 84I. See also Gerberding, Rise of the Carolingians: especially r7.

${ }^{4 \mathrm{~T}} \mathrm{~F}$ or the edition and a translation into English, see (Ps.) St. Jerome, Cosmography of Aethicus Ister.

${ }^{42}$ For the dating, see Herren, 'Introduction': especially lxi, lxxvii, civ. See also Herren, 'The "Cosmography" of Aethicus Ister: Speculations': especially IOI-O2.
} 
of later sources such as those by Isidore $(560-636)$ as well as the $L H F .43$ The Trojans and Troy appear rather occasionally in the Cosmographia, ${ }^{44}$ yet in Chapters IO2 and IO3, depicted as in conflict with the Romans, the Franks are linked to the Trojans. ${ }^{45}$ Thus, given also the two accounts already available in the Chronicle of Fredegar from the previous century, by 75 , that is, before the Merovingian rule came to an end, there were at least four different accounts in circulation, narrating the Trojan origins of the Franks.

The middle of the eighth century marked a turning point in Frankish history. ${ }^{46}$ As

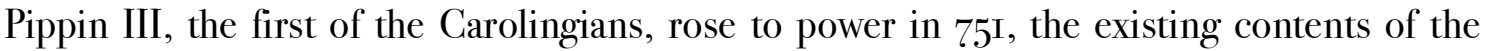
seventh-century Chronicle of Fredegar were re-arranged with further additions that resulted in a new compilation, the Historia vel gesta Francorum (hereafter HGF) ['The History or Deeds of the Franks']. ${ }^{47}$ In this version, along with other changes, the record of events was extended until about $768.4^{8}$ It is assumed that there were two stages of composition. ${ }^{49}$ In the first, the contents of the Chronicle of Fredegar were re-arranged and the narrative was continued to $75^{\mathrm{I}}$ using information found in the $L H F$. This is thought to have been commissioned by Childebrand I (678-75I), brother of Charles Martel (c. 686-74I), who was the father of Pippin III. This work is then thought to have been continued until about 768 under the commission of Nibelung, son of Childebrand I. What is crucial with regard to this 'new' compilation, irrespective of the exact stages of production, is that the passages that told the story of the Trojan origins of the Franks in both the Scarpsum de Cronica Hieronimi and the Scarpsum de Cronica Gregorii of the Chronicle of Fredegar were kept exactly as they were. In addition, the compilers of the $H G F$ clearly had access to the $L H F$, which they utilised for expanding the

\footnotetext{
${ }^{43}$ See Herren, 'Introduction': xxxiii-lv. See also Herren, 'The "Greek Element" in the Cosmography of Aethicus Ister'. For genre and style, see especially Herren, 'The Cosmography of Aethicus Ister: One More Latin Novel?'.

${ }_{44}^{4}$ Troy is mentioned in relation to a certain kind of ship that reportedly was used during the siege in Chapter 57 and in relation to a geographical description in Chapter 74. It also is said that the Amazons pillaged Troy and the surrounding area in Chapter 68.

45 Cosmography of Aethicus Ister: 202-2O7. Krusch separately edits these parts contained in the Cosmographia. See (Ps.) St. Jerome, 'Origo Francorum duplex': 525-27. Herren is doubtful about the 'author's interest in the origin of the Franks'. See Herren, 'Introduction': lxxiv. The author might not have been interested in politics per se but that they were interested in the story of the Trojan origins of the Franks, and, at the very least, that they were aware of the contemporary intellectual exchange on this particular issue are clear.

${ }^{4}$ Wood, Merovingian Kingdoms; McKitterick, Frankish Kingdoms Under the Carolingians.

${ }^{47}$ The title of this eighth-century compilation comes from the unique colophon found in Vatican City, BAV, Reg. Lat. 2I3. Even though this is essentially a different compilation, there is no separate edition of the work other than the combined version with the Chronicle of Fredegar. The manuscripts of this version are identified as Class 4 by Krusch. Collins sets out to demonstrate that these two versions should be considered separate works; see especially Collins, Fredegar-Chroniken: I-7.

${ }^{4} \mathrm{M}$ Much attention has been paid to the contemporary additions made to cover the years from $64_{2}$ to 768 , and specifically this part has been identified as the 'Continuations' of the Chronicle of Fredegar. The modern edition is also organised in this manner, comprising four books and continuations as a separate book. See also Fourth Book of the Chronicle of Fredegar, edited and translated by Wallace-Hadrill. ${ }^{49}$ For the title, date and authorship, see Collins, Fredegar-Chroniken: especially 82-96. Krusch had argued for three stages of composition: Chapters I-I7, I8-34, and 35-54. See Krusch, 'Die Chronicae des sogenannten Fredegar II': 495-5I5.
} 
narrative. $5^{\circ}$ Thus, they had access to all three versions of the story: the two that were already included in the Chronicle of Fredegar and the one that opened the $L H F$. Yet they did not revise those parts of the Chronicle of Fredegar and integrate the information found in the LHF. This provided a new momentum for the circulation of these 'old' stories in a different context. Even more interestingly, there also are surviving manuscript witnesses that date from as early as the second quarter of the ninth century that include the $L H F$ with further additions from the later parts of the $H G F .^{5^{\mathrm{I}}}$ In these manuscripts, too, there is no attempt to rewrite the earlier origin story as found in the $L H F$, even though the scribes might have had access to the other versions.

Possibly before the $H G F$ took its final form around the 770 , if not even before that, another short work was composed, devoted exclusively to the story of the Trojan War and the Trojan origins of the Franks. Entitled the Historia de origine Francorum ['The History of the Origin of the Franks'], this work is attributed to Dares of Phrygia. ${ }^{5^{2}}$ It is in fact a re-narration of the late antique De excidio Troiae historia ['The History of the Destruction of Troy'], which was also attributed to Dares of Phrygia, with further additions to the text. ${ }^{53}$ Claiming to be an eyewitness account that was translated from Greek, the De excidio narrates the Trojan War in a brief manner that makes up 44 short chapters in the modern edition. ${ }^{44}$ The story, which includes events that extend over a period of more than Io years, opens with the expedition by Jason and the Argonauts to Colchis and concludes with the immediate aftermath of the fall of Troy. In the De origine, the existing narrative was shortened and many details were omitted, changed or simply miscopied. ${ }^{55}$ The divergences between the two texts are so many that even though he maintains that the Deorigine agrees on the essential points with the Deexcidio, Paris argues that the work must have been abridged from memory. ${ }^{6}$ Similarly, Jung states that "son récit ne remonte pas à un Darès développé, comme on l'a soutenu, mais doit avoir été composé de mémoire'. ${ }^{7 z}$ Furthermore, in addition to this very heavy redaction and rewriting of the $D e$ excidio, a number of new elements containing the story of the Trojan origin of the Franks were introduced into the narrative in the De origine.

It is not known exactly when, where and by whom the De origine was composed. The text now only survives in the same manuscript witnesses to the $H G F$. Even though the former

$5^{\circ}$ There is no reason to think that they did not have the complete text, regardless of the version they might have had, as there is no manuscript evidence to suggest that parts of the $L H F$ circulated separately.

${ }^{5 I}$ The earliest such example is Paris, BNF, Lat. IogII (Part II). See the discussion in Yavuz, 'Transmission and Adaptation': I79-8I.

$5^{2}$ There are two nineteenth-century editions under the same title by Paris and Krusch, respectively: Historia Daretis Frigü de origine Francorum.

${ }^{53}$ This work is dated to some time between the fourth and sixth centuries. For the edition, see Dares of Phrygia, Daretis Phrygü de excidio Troiae historia; for a translation into English, see Dares of Phrygia, 'The Fall of Troy: A History by Dares the Phrygian'.

${ }^{54}$ For whether or not there was a Greek version and the dating of the Latin text, see Yavuz, 'Transmission and Adaptation': 50-55.

${ }^{55}$ For example, Agamemnon's brother and Helen's husband is Memnon instead of Menelaus, and there is no Neoptolemus but a Triptolemus. Further examples are provided by Paris in his edition: Dares of Phrygia, Historia Daretis Frigü de origine Francorum: I30-37. See also Jung, 'L'historie grecque': I9o. ${ }^{5}$ Paris, Historia Daretis Frigü de origine Francorum: $130-3$ I.

${ }^{57}$ Jung, 'Historie grecque': 190. 
appears to be an integral part of the latter, and has been treated as such in modern scholarship, when the manuscript evidence is considered, this seems unlikely. $5^{8}$ Paris argues that the 'second continuator' of the Chronicle of Fredegar inserted the De origine into the compilation. ${ }^{59}$ Collins, on the other hand, argues that this short work was specifically composed for the $H G F$ even though he accepts that the rewriting that went into the De origine is fundamentally different and much more extensive than the other changes introduced in the rest of the compilation. ${ }^{60}$ Given also that it is inserted in between chapters of the excerpt from Jerome's Chronicon in the $H G F$, it seems more likely that this short work was composed separately, and perhaps even circulated separately, and was then attached to the $H G F$ at a very early stage. ${ }^{6 \mathrm{r}}$

Possibly within a few years of the completion of the $H G F$, another chronicle surfaced, which includes two narrations of the story of the Trojan origins of the Franks: the Chronicon universale usque ad annum 741 ['The Universal Chronicle up to the Year 74I'], as it is known in modern scholarship. ${ }^{62}$ This time, the framework for the compilation was Chapter 66 of the De temporum ratione ['The Reckoning of Time'] by Bede the Venerable (672-735)-also known as his Chronica maiora or the World Chronicle. ${ }^{63}$ Thought to be completed in 725, the De temporum ratione focuses on the calculation of the date of Easter. Much like some other works by Bede, the De temporum ratione reached the continent quickly and began circulating very rapidly. ${ }^{64}$ In addition, Chapter 66 of the De temporum ratione, titled De sex huius mundi aetatibus ['Six Ages of This World'], also circulated on its own from very early on as both a copy detached from the rest of the work and in extended and expanded versions. ${ }^{65}$ Bede's Chronica maiora enjoyed a continued and wide circulation in the Frankish region and was

\footnotetext{
${ }^{58}$ Krusch, 'Die Chronicae des sogenannten Fredegar II': $5^{\mathrm{I} 2 .}$

${ }^{59}$ Paris, Historia Daretis Frigï de origine Francorum: 129.

${ }^{60}$ Collins, Fredegar-Chroniken: 83-85.

${ }^{6 \mathrm{r}}$ Yavuz, 'Transmission and Adaptation': 185-87.

${ }^{62}$ Until recently, there was only a partial edition comprising selected passages: Chronicon universale, 'Chronicon universale - 741, cum continuatione'. Recently, the witnesses of the work were collated as part of the edition of the Chronicon Moissiacense by Claszen. It should be mentioned, however, because its focus is the Chronicon Moissiacense and not the Chronicon universale, which was one of the sources of the former; Claszen's edition takes the most recent surviving witness to the Chronicon universale as its basis (Paris, BNF, Lat. 4886). Quotations will be from the earliest manuscript witness, Leiden, UBL, SCA 28.

${ }^{6}$ For Bede's work, see 'De temporum ratione'. For the translation, see Reckoning of Time. The precursor of this work was Bede's De temporibus dated to 7O3, a smaller handbook, again on computus which also included another, shorter world chronicle.

${ }^{64}$ For the circulation of Bede's works, see Laistner, Hand-List of Bede Manuscripts. Note that several errors and omissions have been recorded since the publication of this book; however, it still serves as a useful guide for the bigger picture. See also Lapidge, 'Beda Venerabilis': especially $65^{-68}$.

${ }_{55}$ Dumville, 'What Is a Chronicle?': I4. Sometimes, the final part of the De temporum ratione comprising the Chapters $67_{-7} \mathrm{I}$, which are collectively called 'Future Time and the End of Time', was also attached to these copies containing Chapter 66 . For the six-age model and its expansion in the De temporum ratione, see Darby, Bede and the End of Time: I5-9I.
} 
especially used as a template for later anonymous compilations. ${ }^{66}$ The Chronicon universale is one of the earliest examples of such reworking undertaken in the Frankish realm. As it may be deduced from its modern title, beginning with Adam, the Chronicon universale narrates the history until the year $74 \mathrm{r} .{ }^{67}$ Utilising the framework of the six ages of the world as well as most of the material already found in Bede's Chronica, the anonymous author incorporates a broad range of information from the works of other authors including Jerome, Augustine, Eutropius, Isidore and Orosius. The author also makes use of the $L H F$ and either the Chronicle of Fredegar or the $H G F$. One of the characteristics of the Chronicon universale is that the majority of the interpolations are not randomly inserted verbatim from these sources; instead, they are carefully rephrased, reworked and interwoven into Bede's Chronica without disrupting its original flow. Another important feature is that the interpolations primarily serve to expand on Frankish history, which gradually becomes the main focus of the work.

In addition to the particulars of the Trojan story in each of these works, the methods of rewriting employed by these authors are quite striking. First of all, as already noted, throughout the Trojan origin story found in the first four chapters of the $L H F$ there is no reference to the Chronicle of Fredegar, and it agrees with the earlier two accounts only in the broadest outline. Thus, it has been argued that the story of Trojan origins in the LHF is independent of either of the two accounts found in the Chronicle of Fredegar. On the other hand, the $L H F$ is one of the sources of the Cosmographia and whether the author used the Chronicle of Fredegar is still controversial. The story as it is narrated in the LHF, however, is not used in the part of the Cosmographia that specifically deals with the Franks and Trojans. Instead, details of the story as it is told in the Cosmographia are only found in the De origine attributed to Dares of Phrygia. And, the latter work is found today only attached to the HGF in the surviving manuscripts. The $H G F$, on the other hand, keeps the two accounts of the Trojan origins of the Franks as they are found in the Chronicle of Fredegar despite the fact that in other parts it utilise s the $L H F$ to expand the narrative. Finally, the Chronicon universale utilises both accounts in the Chronicle of Fredegar as well as incorporating information from the $L H F$. Here, moreover, none of these three versions of the story was merely copied but yet other versions were created through a very careful rewriting.

Thus, during the mid-eighth century, in a very short span of time, the story of the Trojan origins did not only become widespread but also was translated from the historiography of the Merovingians into that of the Carolingians. These works were composed in an age of great transformation for the Frankish world and they very subtly reconfigured the Trojan narrative and the history of the Franks for centuries to come. The existence of the Chronicle of Fredegar as well as the $H G F$ combined with the De origine shows that the early medieval audience was able to accommodate the differences in the accounts and that two or three versions of the story with different details could circulate together for an extended period of time. On the other hand, the Chronicon universale attests to the use of both the Chronicle of Fredegar and the $L H F$. This means that these two works were in the same scriptorium at the

${ }^{66}$ For its later impact in the Frankish realm, see, for example, Garipzanov, 'The Carolingian Abbreviation'; Jones, 'Bede's Place in Medieval Schools': 26I-85.

${ }^{67}$ The last entry in the Chronicon universale corresponds to the reign of Emperor Constantine V, to years 74I-775; however, there are no indications as to which year of his reign. For the dating, see Kurze, 'Karolingischen Annalen': 293; Claszen, Chronicon Moissiacense, vol. I: 54-55. 
same time by the mid-eighth century or shortly thereafter. Furthermore, it shows that these two works also have not necessarily been seen as two conflicting or competing histories and that the reader/compiler could easily integrate the information contained in them to have a fuller understanding of the past. Rewriting and reorganisation of information in its widest terms are at the heart of the connections among these works, which have complex textual and material relationships. Not only was the reuse of previous material involved in the production of these works but also, in terms of the particulars of the Trojan origin story, different details were included in each account even when one is able to prove that a certain author had access to and even utilised a certain other work that already included the story.

This high point in the engagement with the story of the Trojan origins of the Franks during the eighth century cannot be a mere coincidence. Not only the textual evidence but also the survival of the Merovingian works that include the story in Carolingian manuscript compilations indicate that right from the start, beginning with the reign of Pippin III, the Carolingians used this tradition inherited from the Merovingians as a means to legitimise their rule over the Franks. By the last quarter of the eighth century, as Charlemagne (Charles I, r. 768-8I4) rose to power, it may be surmised that the Trojan origin of the Franks had already become a very-well established 'fact' in Frankish history. The claim to Trojan origins during the Merovingian times, a clear act of imitatio imperï derived from their Gallo-Roman heritage, had already placed the Franks in the same picture with the Romans. ${ }^{68}$ The continued appropriation of the Trojan origin story during the early years of the Carolingians would not only give the Franks a longer history but also enable them to actually become one with the Romans with Charlemagne's coronation as the Holy Roman Emperor in 800.

\section{The Franks: Origins, Kings and the People}

Both the ancestry of the Frankish kings and the naming of the Frankish people are deeply intertwined with the Trojan origin story of the Franks. In the Chronicle of Fredegar, it is repeated several times that the Franks took their name after their 'elected' king Francio, who is of Trojan lineage. In the fifth chapter of the Scarpsum de Cronica Hieronimi, titled 'De Francione rigi Francorum et Francis' ['On Francio, king of the Franks, and the Franks'], the election of the king and the explanation regarding the name of the people are provided together: 'electum a se regi Francione nomen, per quem Franci vocantur' ('with a king having been elected by themselves, Francio by name, on account of whom they are called Franks'). ${ }^{69}$ In the Scarpsum de Cronica Gregorii, again, the election of the king(s) and the naming of the people(s) after the name of their king(s) are handled together: "elictum a se Torcoth nomen regem, per quem ibique vocati sunt Turchi; et per Francionem hii alii vocati sunt Franci' ('with a king having been elected by themselves, Torcoth by name, on account of whom those there are called Turks, and on account of Francio those others are called Franks'). ${ }^{\circ}$ Later in the same section, the author of the Chronicle of Fredegar once more returns to the subject of election and lineage of kings, in which passage it is underlined that the kings of the Franks, including Francio, are of Trojan lineage: 'Franci electum a se regi, sicut prius fuerat, crinitum,

\footnotetext{
${ }^{68}$ See Scholl, 'Imitatio Imperii?'; McCormick, Eternal Victory.

${ }^{69}$ Fredegar, Chronicarum quae dicuntur Fredegarï: 46 (II.5).

${ }^{70}$ Fredegar, Chronicarum quae dicuntur Fredegarï: 93 (III.2).
} 
inquirentes diligenter, ex genere Priami, Frigi et Francionis super se creant nomen Theudemarem' ('The Franks, diligently inquiring, created over themselves a longhaired king, chosen by themselves as they had before, Theudemer by name, from the stock of Priam, Frigus, and Francio'). ${ }^{71}$ Here the names of Priam, Frigus and Francio are explicitlylisted and it is stated that the kings of the Franks are all from the Trojan stock and that the people kept electing kings from this stock. Although at least beginning with Theudemer the reign passes from father to son, for example, it is still emphasised later in this chapter that Chlodio, son of Theudemer, who was later elected as king, was also 'the most suitable' ('utilissimus') for the job in his gens. The author of the Chronicle of Fredegar, however, is not the first to mention a leader from whom the Franks received their name. The sixth-century historian John the Lydian, for example, states that 'they are called the Franks after their leader' even though he does not provide a name for this leader. ${ }^{2}$ Similarly, in the seventh century, in his Etymologiae, Isidore of Seville also mentions that 'the Franks are thought to have been named after a certain duke of theirs'. 73

In the Cosmographia, a Francus and a Vassus are presented as brothers 'qui ex regia prosapia remanserant' ('who were survivors of the royal line') of the Trojans. ${ }^{74}$ Unlike the Chronicle of Fredegar, the Romans, although mentioned in the work, are not associated with the Trojans, and the Turks, who are clearly associated with the Trojans and specifically with the Franks in the Chronicle of Fredegar, are depicted rather negatively and are not related to either the Trojans or the Franks in any way. ${ }^{75}$ An interesting aspect of the story of the two brothers as it is found in the Cosmographia is that the combination of Francus and Vassus as heirs of the Trojans is only found in one other work, the De origine, attributed to Dares of Phrygia. After the abridged version of the story of the fall of Troy, towards the end of the narrative, the De origine moves on to the story of the Trojan origins of the Franks. Here the reader learns more about their lineage: 'Pherecides genuit alium Frigionem. [...] Qui Frigio genuit Franco et Vasso elegantissimis pueris adque efficaces' ('Pherecides begat another Frigio. [...] This Frigio begat Francus and Vassus, the most elegant and efficacious boys'). ${ }^{6}$ Even though this short passage seems to provide more details in comparison to the Cosmographia, it raises more questions than it gives any answers. For example, not only is this ancestor of the Franks, Pherecides, otherwise unaccounted for before its appearance here, but the reader also is introduced to an 'alium Frigionem' without a mention of any other Frigio in the text. As the date of neither work is securely known, it cannot be assumed that the author of the Cosmographia was familiar with the De origine or vice versa. Furthermore, despite the Trojan link, neither the author of the Cosmographia nor the De origine directly relates the name of Francus to the people of the Franks.

\footnotetext{
${ }^{7}$ Fredegar, Chronicarum quae dicuntur Fredegarï: 94-95 (III.9).

$7^{2}$ John the Lydian, On Powers: 2 I8 (III.56).

${ }^{73}$ Isidore of Seville, Etymologiarum sive originum: IX.2.IOI 'Franci a quodam proprio duce vocari putantur'. For the translation, see Etymologies: 198.

${ }^{74}$ (Ps.) St. Jerome, Cosmography of Aethicus Ister: 202-O3 (Chapter IO2).

${ }^{75}$ Chapters 62-64. For a discussion of the depiction of the Turks in the Cosmographia, see Wood, 'Aethicus Ister: An Exercise in Difference'.

${ }^{7}$ Historia Daretis Frigï de origine Francorum, edited by Krusch: 199 .
} 
In the $L H F$, on the other hand, the very first sentence of the work is already very evocative: 'Principium regum Francorum eorumque origine vel gentium illarum ac gesta proferamus' ('Let us make known the beginning of the kings of the Franks, their origins and the origins and the deeds of those gentes ). ${ }^{77}$ In some manuscripts, this beginning sentence is presented as 'Principium quoque Francorum gentis origine vel regum gesta proferamus' or 'Principium quoque Francorum gentis origine vel regum gesta proferamus vel cuncta audiamus'..$^{8}$ Despite the small changes in the wording, the emphasis remains the same: the account will narrate both the reges and gentes and will be about both their origo and their gesta. The reader is thus promised a narration on both the kings and the people of the Franks and a history on both their origins and their deeds. After this straightforward and grand opening, however, the author continues with a very brief account of the Trojan War that includes the journey of the Trojans after the fall of the city. In this version, there are no Macedonians or Turks. With regard to Romans, the account only reports that Aeneas went to Italy to raise more men for the fight; however, there is no mention of what happens to Aeneas afterwards, nor is there any reference to Aeneas (or the Trojans) founding Rome or to the Trojans being the ancestors of the Romans. The sole interest of the author of the $L H F$ remains to be the Franks and their origins, that is, their Trojan origins.

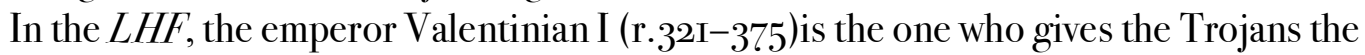
name 'Franks' due to their bravery against the Alans. ${ }^{79}$ Here, it is also stated that the name Frank/Francus comes from the word 'feros' ('fierce') in 'attica lingua' ('Attic language') and that this is why the people are named the Franks. Thus, the author of the $L H F$ explains where the name of the people comes from without needing to invent a king called Francio/Francus like the author of the Chronicle of Fredegar does. Nevertheless, what the author of the LHF does is not something new either. After stating that 'the Franks are thought to have been named after a certain duke of theirs', Isidore also mentions that 'others reckon that they were named for the ferocity of their behaviour, for their behaviour is wild, with a natural fierceness of spirit'. ${ }^{80}$

Having access to both the Chronicle of Fredegar and the $L H F$, the author of the Chronicon universale tackles the origins and the naming of the Franks in a different manner. In addition to providing more information on the Trojans and the Trojan War in other parts of the work, the author integrates the story of the Trojan origins of the Franks into the grand narrative of Bede's Chronica maiora by rewriting the different elements of the story. The story of the Trojan origins of the Franks is found in two sections of the Chronicon universale. In the first instance, the source of the author is the Scarpsum de Cronica Hieronimi found in the Chronicle of Fredegar-and also, in the HGF. The author carefully reorganises the relevant chapters and weaves them into the text. Here, the reader once again learns that the Franks elected a king Francio after whom they got their name: 'electum a se rege Francione nomine,

\footnotetext{
77 LHF: 24I.

$7^{8}$ LHF: 235; 24I.

${ }^{79}$ LHF: 243.

${ }^{80}$ Isidore of Seville, Etymologiarum sive originum: IX.2.IoI: 'alii eos a feritate morum nuncupatos existimant. Sunt enim in illis mores inconditi, naturalis ferocitas animorum'. For the translation, see Etymologies: 198.
} 
per quem Franci vocantur in postremum'. ${ }^{81}$ In this instance, no attempt has been made to bring in information from the other accounts.

At a later part of the Chronicon universale, however, after narrating the reign of the emperor Honorius (r. 393-423), the author mentions the story of the Trojan origins of the Franks again. This time, the author rewrites a new account by interweaving the version included as part of the Scarpsum de Cronica Gregorii in the Chronicle of Fredegar with the version in the $L H F$. The author begins the story with the excerpt from Gregory's Historiae found in the Chronicle of Fredegar, which begins as follows: 'De Francorum vero regibus beatus Hieronimus, qui iam olym fuerant, scripsit, quod prius Virgilii poetae narrat storia: Priamum primum habuisse regi [...] postea Frigam habuissent regem' ('Concerning the kings of the Franks, blessed Jerome has written who they were once upon a time, and before him the poet Virgil told the story. They had Priam as their first king [...] afterwards they had Frigas as king'). ${ }^{82}$ Instead of copying this sentence verbatim, the author writes: 'Franci vero, quorum originem beatus Hieronimus meminit, qualiter a Troia usque ad Renum pervenissent cum rege suo Francione'. ${ }^{3} 3$ They edit 'reges Francorum' to 'Franci', a significant alteration, and thereby state that Troy is the origin of the 'people of the Franks' and that not only the kings but also the people came from Troy. They also add the name of the king of the Franks, 'Francio', whose name is only mentioned in the Chronicle of Fredegar and not in the LHF. The author then continues 'Quo mortuo, duces ex se constituerunt, nec procul a Reno civitatem ad instar Troiae edificare conati sunt, quam Sicambriam appellaverunt'. ${ }^{84}$ That the Franks established duces after the death of Francio is taken from the account in the Chronicle of Fredegar but that they established a city and named it Sicambria is taken from the first chapter of the $\mathrm{LHF}^{8}{ }^{85} \mathrm{Each}$ of these pieces of information is unique to the respective accounts and is not found in the other, but the author of the Chronicon universale carefully pieces them together. Yet, as the author tries to streamline the different versions, the result omits the explanation that the Franks got their name due to their 'ferocity' and through the emperor Valentinian, even though his dealings with the Franks are mentioned.

In addition to kings of the Franks coming from Trojan stock and the people of the Franks being named after one of their kings, the Chronicle of Fredegar states that the Merovingians received their name from Merovech, another king of the Franks: 'Meroveum, per co [i.e., per quo] regis Francorum post vocantur Merohingii' ('Merovech, through whom the kings of the Franks are afterwards called the Merovingians'). ${ }^{86}$ Merovech is portrayed as the son of Chlodio, whose lineage is expressly tied to Priam, the first king of the Trojans. ${ }^{87}$ Traced directly to the Trojans, the Chronicle of Fredegar is the first work to name the Merovingian dynasty and to legitimise their reign over the Franks by underlining their Trojan ancestry. Thus, as the first surviving work to contain accounts of the Trojan origins of the Franks, the

\footnotetext{
${ }^{8 \mathrm{r}}$ Leiden, UBL, SCA 28, fol. 97v. Compare Claszen, Chronicon Moissiacense, vol. 2: 19.

${ }^{82}$ Fredegar, Chronicarum quae dicuntur Fredegarï: 93 (III.2).

${ }^{83}$ Leiden, UBL, SCA 28, fol. I2Iv. Compare Claszen, Chronicon Moissiacense, vol. 2: 79 .

${ }^{84}$ Leiden, UBL, SCA 28, fol. r2rv. Compare Claszen, Chronicon Moissiacense, vol. 2: 79.

${ }^{85}$ LHF: 242.

${ }^{86}$ Fredegar, Chronicarum quae dicuntur Fredegarï: 95 (III.9).

${ }^{87}$ On the supernatural elements about the birth of Merovech, see Murray, 'Post Vocantur Merohingi'; Wood, 'Deconstructing the Merovingian Family'.
} 
Chronicle of Fredegar not only links the people of the Franks to the Trojans through Francio but also ties the ruling dynasty of the Merovingians directly to the Trojan Priam through Merovech.

Merovech also figures in the LHF: 'Chlodione rege defuncto, Merovechus de genere eius regnum eius accepit. [...] Ab ipso Merovecho rege utile reges Francorum Merovingi sunt appellati' ('After Chlodio died, Merovech who was from his genus took over his kingdom. [...] From this suitable king Merovech, the kings of the Franks are called the Merovingians'). ${ }^{88}$ Differently from the Chronicle of Fredegar, however, Merovech is only mentioned as from the same genus as Chlodio and not as his son. Furthermore, earlier in the same chapter, Chlodio's father is named as Pharamund and not Theudemer: 'Mortuo quippe Faramundo rege, Chlodionem, filium eius crinitum, in regnum patris sui elevaverunt' ('After King Pharamund died, they raised up into his father's kingdom his long-haired son Chlodio. From this time, they began to have long-haired kings'). ${ }^{89}$ Even though through a different parentage, Chlodio's lineage is again expressly tied to Priam, the first king of the Trojans according to the $L H F$. The author of the Chronicon universale connects the Merovingians to the Trojans through Merovech as well: 'Clodionem regem defuncto [...] Meroveus in regno sublimatus est, filius eius, a quo reges Francorum Merohingi vocantur'.$^{\circ}$ According to the information taken from the Chronicle of Fredegar, once again, Merovech is portrayed as the son of Chlodio. Yet, information on Chlodio's father is taken not from the Chronicle of Fredegar but from the $L H F$, and his name is given as Pharamund. This may be seen as the first attempt to streamline the genealogy of the first kings of the Franks and of the Merovingian dynasty.

\section{Charlemagne, Troiane gentis rex}

Charlemagne, the most famous of the Carolingian kings, succeeded his father Pippin III and became king of the Franks in 768 . By this time, the Trojan origins of the Franks, not to mention of the Merovingian dynasty, must have been already established. Evidenced by the surviving manuscripts of works produced either during the Merovingian times or during the very early years of the Carolingians, and by other works that utilise information derived from these works, it is clear that the Carolingians also placed importance on this origin story. Indeed, the story must have become so common that Charlemagne's contemporary Paul the Deacon (c. 720-799) simply stated it to be ordinary knowledge that the Frankish people came from the Trojans in his Liber de episcopis Mettensibus ['The Book on the Bishops of Metz']: 'Nam gens Francorum, sicut a veteribus est traditum, a Troiana prosapia trahit exordium'..$^{\mathrm{I}}$

The De episcopis Mettensibus is thought to have been commissioned by Angilram, bishop of Metz, during Paul's short sojourn in Francia. ${ }^{22}$ As far as it is known, Paul himself had

\footnotetext{
${ }^{88}$ LHF: 246.

${ }^{89}$ LHF: 245 .

$9^{90}$ Leiden, UBL, SCA 28, fol. I24r. Compare Claszen, Chronicon Moissiacense, vol. 2: 85.

${ }^{91}$ Liber de episcopis Mettensibus: $7^{2}$. For Paul the Deacon, see, for example, McKitterick, History and Memory: 6o-83; Goffart, Narrators: 329-431; and Cornford, 'Paul the Deacon's Understanding of Identity': 47-49.

${ }^{92}$ It is thought that Paul was in Francia sometime from 78 I or 783 to $786 / 87$. See Kempf, 'Introduction’: 2-3; McKitterick, History and Memory: 67.
} 
no links to Metz and, therefore, had no obvious reason to compile an episcopal history for it. However, not only did the city of Metz have close associations with the Carolingian family but Angilram also had been appointed archbishop by Charlemagne in 784 , around the time when Paul composed the De episcopis Mettensibus. ${ }^{93}$ Goffart states that 'as an episcopal history compared to others of the type, Paul's work is skeletal, unsatisfactory, and almost wholly untainted by archival and other local information'. ${ }^{44}$ Indeed, the author is more interested in using the episcopal history as a framework than in narrating the biographies of all the bishops at length. A good portion of the work, therefore, is devoted to the life and accomplishments of Arnulf, former bishop of Metz, as well as the rest of the Carolingian house, including of course Charlemagne, king of the Franks at the time, at whose invitation Paul was in Francia. ${ }^{95} 95$ And it is important to note that Arnulf not only was a former bishop of Metz but also had been sainted, and perhaps more importantly in this context, he was Charlemagne's great-greatgreat-grandfather. ${ }^{96}$

The Trojan narrative has a very small but significant part to play in the De episcopis Mettensibus. After dealing with the earlier bishops of Metz, Paul begins his account of Arnulf by reporting one of his miracles. ${ }^{97}$ Already here Arnulf is described as 'vir per omnia lumine sanctitatis et splendore generis clarus' ('a man glorious in all respects by the light of his sanctity and the fame of his genus') and 'ex nobilissimo fortissimoque Francorum stemate ortus' ('coming from a most noble and powerful Frankish stock'). ${ }^{8}$ Furthermore, at the end of the account, the reader learns that this is no ordinary story; the author states that he learned it from Charlemagne himself. ${ }^{99}$ With this statement, Paul not only refers to his personal connection with the great king himself but also reveals his real purpose: to narrate Charlemagne's lineage. Immediately after this disclosure, 'he returns to his subject' and begins with Arnulf's sons:

Nam venerandus iste vir, ut ad superior redeam, iuventutis sue tempore ex legitimi matrimonii copula duos filios procreavit, id est, Anschisum et Chlodulfum; cuius Anschisi nomen ab Anchise patre Aenee, qui a Troia in Italiam olim venerate, creditor esse deductum. Nam gens Francorum, sicut a veteribus est traditum, a Troiana prosapia trahit exordium.

\footnotetext{
${ }^{93}$ See Kempf, 'Introduction': 4-7 for Angilram at the court of Charlemagne, and 8 for the dating of the work.

${ }^{94}$ Goffart, Narrators: 373 .

${ }^{95}$ Goffart, Narrators: $34{ }^{\mathrm{I}-42}$, argues that Paul was at the court of Charlemagne from 78I to early 784 .

${ }^{96}$ See Kempf, 'Introduction': especially 8-IO and Goffart, Narrators: especially 374-77.

${ }^{97}$ This miracle is absent from both the Vita Arnulfi and the Chronicle of Fredegar, the two sources that extensively talk about Arnulf to which Paul might have had access; see Wood, 'The Use and Abuse of Latin Hagiography'.

${ }^{98}$ Paul the Deacon, Liber de episcopis Mettensibus: 70-7I.

${ }^{99}$ Paul the Deacon, Liber de episcopis Mettensibus: 72-73: 'hec ego non a qualibet mediocri persona didici, sed ipso totius veritatis assertore, precelso rege Karolo, referente cognovi; qui de eiusdem beati Arnulfi descendens prosapia ei in generationis linea trinepos extabat' ('I learned this story not from a mediocre man, but from the defender of all truth, the lofty king Charlemagne, who descended from the family of Arnulf, and is his great-great-great-grandson').
} 
To return to my subject: when he was young, this venerable man Arnulf had two sons from a legitimate marriage, namely, Ansegisel ${ }^{100}$ and Chlodulf. The name Ansegisel is believed to be derived from Anchises, father of Aeneas, who once came from Troy to Italy. For the gens Francorum, as it is told by the ancients, sprang from a Trojan lineage. ${ }^{\text {.OI }}$

This is the first account to name Arnulf's sons and in doing so to make a connection between Arnulf and Ansegisel who would inevitably lead to Charlemagne. ${ }^{102}$ Furthermore, Ansegisel is reported to be named after a prominent Trojan figure, Anchises, father of Aeneas. Aeneas is only mentioned as someone 'who once came from Troy to Italy' but the readers of this passage surely would have been familiar with both Aeneas and Anchises. ${ }^{103}$ The reason Paul gives for the naming of Ansegisel as such is even more striking: 'For the gens Francorum [...] sprang from a Trojan lineage'. Paul is thus the first author to put the Trojan origins of the Franks as simply as this with no need for further elaboration or justification. He does not only report the gens Francorum to be of Trojan descent but also directly links a prominent member of the Carolingian house to the Trojan migrants. Furthermore, in his Historia Langobardorum, which he wrote after the De episcopis Mettensibus and which is thought be left unfinished due to his passing, Paul not only names Ansegisel as a son of Arnulf and makes the connection with the Trojans but also openly declares him a maior domus of regnum Francorum: 'At this time in Gaul, in the kingdom of the Franks, Ansegisel, the son of Arnulf, who is believed to be named after Anchises the former Trojan, carried out the rule under the title of maior domus'. ${ }^{104}$

The phrasing of Paul in the De episcopis Mettensibus, 'as it is told by the ancients' ('sicut a veteribus est traditum'), is even more interesting as it implies a long and established tradition; yet, it does not give any clues as to from where he might have gotten this information. ${ }^{\text {Io5 }}$ Even though the connection with the Trojans or Arnulf was not made,

\footnotetext{
${ }^{100}$ Also known as Ansegisus in modern literature.

${ }^{10}$ Paul the Deacon, Liber de episcopis Mettensibus: $7^{2}-73$.

${ }^{102}$ Wood, 'Teutsind': 32.

${ }^{103}$ Indeed, Paul himself was certainly aware of the implications of mentioning Aeneas and knew his Aeneid very well, not to mention that in his Historia Romana (c.770), Paul details the Trojan origins of the Romans following a variety of sources including those of Livy, Orosius, Virgil and Servius despite the fact that his main source, Eutropius's Breviarum ab urbe condita, does not associate the Trojans with the founding of Rome. See Paul the Deacon, Historia Romana: 8-II.

${ }^{104}$ Paul the Deacon, Historia Langobardorum: I72 (VI.23): 'Hoc tempore apud Gallias in Francorum regnum Anschis, Arnulfi filius, qui de nomine Anschise quondam Troiani creditor appellatus, sub nomine maioris domui gerebat principatum'. For the translation, see Paul the Deacon, History of the Lombards: 266.

${ }^{105}$ Kempf argues that Paul 'knew' the Chronicle of Fredegar even though he later contradicts himself and states that 'there is no direct evidence that he [Paul] read the Chronicle of Fredegar'. See Kempf, 'Introduction': I3; I3, n. 48. Note also that Paul does not utilise any information about Arnulf from the Chronicle of Fredegar for his De episcopis Mettensibus. McKitterick, History and Memory: 67, on the other hand, suggests that Paul 'had probably read the Carolingian edition of the Chronicle of Fredegar, and possibly its Continuations', that is, the $H G F$. However, there seems to be only one possible yet contested borrowing from the Chronicle of Fredegar in the entirety of Paul's corpus, and this is from
} 
Ansegisel is already mentioned in the $L H F$ as Pippin II's father. ${ }^{106}$ This information was also later picked up in the $H G F$ where Pippin II was depicted as the 'son of the deceased Ansegisel, a Frank of noble stock' ${ }^{107}$ And, by the turn of the ninth century, it became common even to commence historical works with Pippin II and his descent from Ansegisel, as exemplified by the Annales Mettenses priores and the Chronicon Laurissense breve.

As the story develops in the De episcopis Mettensibus, the reader learns that Ansegisel not only is the one named after his Trojan ancestors but also is clearly the better of the two sons. He is both ready to obey his father's wishes as a good son would do and willing to abandon his riches as an act of piety as a good Christian would do. As a result of his pious actions, not only Ansegisel himself but also his progeny is blessed by Arnulf, and therein lies the success of the Carolingians. ${ }^{\text {I08 }}$ After this, the family line finally reaches Charlemagne, 'who extended the kingdom of the Franks as never before'. ${ }^{109}$ In this passage, in addition to justifying the rule of the Carolingians over the Franks, Paul sketches out the genealogy of the Carolingians. Bouchard underlines the fact that in Paul's 'account all wives and collateral branches of the family are pared away, so that a simple line of father-to-son descent is presented' ${ }^{\text {.о }}$ Indeed, the cycle of Pippin-Charles-Pippin-Charles as direct heirs of Ansegisel is very striking in the passage. ${ }^{\text {II }}$ Kempf argues that "the glorification of the genealogical ties between Arnulf and Charlemagne in Paul the Deacon's Liber needs to be read as an attempt to foster Metz's relations to the Carolingians'. ${ }^{\text {I2 }}$ Moreover, considered in the broader framework of the development of the story of Trojan origins of the Franks in the eighth century, the implications of 'the glorification of the genealogical ties' become even more significant. Paul not only associates the Carolingians with the Trojans but also, as McKitterick points out, 'in subsequently describing Charlemagne as the conqueror of Italy and ruler of Rome, he reunites the two branches of the Trojan diaspora', namely the Franks and Romans. ${ }^{\amalg 3}$

Within only a few years after the composition of the De episcopis Mettensibus, in 787 or 788 , the story of the Trojan origins of the Franks is encountered again. In his poem, an author who identifies himself as Hibernicus Exul not only mentions the story but also takes it to a step further and makes Charlemagne himself address the Frankish people after a recent

Book IV.9 and is found in Paul's Historia Langobardorum. See Goffart, Narrators: 402. For a discussion of sources, see Yavuz, 'Transmission and Adaptation': 20O-OI.

${ }^{106}$ Beginning of Chapter 46 reads: 'Eo quoque tempore, decedente Vulfaldo de Auster, Martinus et Pippinus iunior, filius Anseghiselo a quondam, decedentibus regibus, dominabantur in Austria': 'In that time also, Wulfoald having died in Austrasia, Martin and Pippin the younger, son of late Ansegisel, were dominant in Austrasia because the kings had passed from the scene' (LHF: 319-20).

${ }^{107}$ Fredegar, Chronicarum quae dicuntur Fredegarï: 179 (Continuations, Chapter 97).

${ }^{108}$ Paul the Deacon, Liber de episcopis Mettensibus: 74-75.

109 'Huius item filius magnus rex Karolus extitit, qui Francorum regnum, sicut nunquam ante fuerant dilatavit'. Paul the Deacon, Liber de episcopis Mettensibus: 74-75.

по Bouchard, 'Images': 299.

"m The genealogy as depicted here: Ansegisel, Pippin II, Charles Martel, Pippin III and Charlemagne (Charles I).

피 Kempf, 'Introduction': II. For further elaboration of this argument, see also Kempf, 'Paul the Deacon's Liber de episcopis Mettensibus'.

"з McKitterick, History and Memory: I25. See also Goffart, 'Paul the Deacon's Gesta Episcoporum Mettensium?. 
victory as 'O royal people, sprung from the lofty walls of Troy' ('O gens regalis, profectus a moenibus altis Troiae'). ${ }^{\text {II }}$ The idea of the Trojan origins being endorsed and further spreading is manifested in other, seemingly unrelated works from the era of Charlemagne as well. For example, in the Liber in partibus Donati ['The Book on the Parts of Donatus'], a commentary based on the grammar of Donatus, written by Smaragdus of Saint-Mihiel (c. 76o-840), the reader comes across a subtle yet powerful statement. Another contemporary of Charlemagne (and Paul the Deacon), Smaragdus was active at the court of Charlemagne and then at that of his son, Louis the Pious. ${ }^{\text {I5 }}$ While introducing various grammatical concepts, Smaragdus provides examples. In one of these, on the genitive case, he writes as follows: 'Genitiuus ideo uocatur, quia per eum et genus ostendimus et gentem, ut Carolus, Pipini filius et Troiane gentis rex' ${ }^{\text {II6 }}$ Here Charlemagne is described as 'son of Pippin and the king of the Trojan people'. Smaragdus's source for this passage is Priscian's Institutiones Grammaticae ['Foundations of Grammar'], thought to have been completed in c. $5^{26 / 7}$ and not any of Donatus's works. Even more strikingly, all the examples provided by Priscian on this topic are related to Priam, who is not even described as the king of the Trojans. ${ }^{\text {It }}$ Furthermore, in one ninth-century manuscript of the work, Charlemagne's name is replaced with that of his son Louis, who succeeded him in 8I4: 'Lodovicus, Karoli filius et Troiane gentis rex': 'Louis, son of Charles and the king of the Trojan people'. ${ }^{\text {ㅇ }}$ The statement by Smaragdus and the alteration by the scribe of the later copy of his work are powerful indications not only that the story of the Trojan origins of the Franks was widespread during the reign of Charlemagne (and afterwards) but also that the tradition was endorsed by the Carolingian house.

\section{Charlemagne's Legacy: The Trojan Origins of the Franks}

Almost a century after the composition of the $L H F$, Frechulf of Lisieux also included the story of the Trojan origins of the Franks in his Historiarum libri XII ['Twelve Books of History'] dated to 829/30. ${ }^{119}$ Frechulf, bishop of Lisieux at the time, was close to the court of Louis the Pious, Charlemagne's son and successor, who was to reign for another decade. It has been argued that Frechulf wrote this lengthy 'world history' that stretched from the creation of the world to his times for the education of the future king, Charles the Bald, Louis the Pious's son and successor. ${ }^{120}$ Another noteworthy point of the story of the Trojan origins of the Franks as it is narrated in Frechulf's Historiae is that Frechulf's source text is the De origine. Frechulf

\footnotetext{
${ }^{{ }_{4} 4}$ Hibernicus Exul, Hibernici Exulis et Bernowini carmina: 398 (11. 85-86). For a partial translation and discussion, see Garrison, 'The Franks as the New Israel?': I5O-52.

"I5 On the importance of grammatical education according to Charlemagne, see Law, 'The Study of Grammar'.

${ }^{ }{ }^{16}$ Smaragdus, Liber in partibus Donati: 76.

${ }^{\text {}} 7$ Smaragdus does not only change the names but completely rewrites the passage. See Priscian, Prisciani Institvtionvm grammaticarvm libri I-XII: 185 (V.72).

${ }^{\text {n8 }}$ Paris, BNF, Lat. I3O29, fol. 2or. For a detailed discussion and partial transcriptions, see Manitius, 'Zur karolingischen Literatur': 6o-75.

"r9 Frechulf of Lisieux, Historiarum libri XII.

${ }^{120}$ McKitterick, 'Charles the Bald (823-877) and His Library'. See also Innes, 'Teutons or Trojans?': 233 .
} 
not only includes a 'free' adaptation of the story based on the De origine but also cites Dares of Phrygia as his source for the origin story. ${ }^{\text {I2I }}$ Thus, not only is the history of the Franks placed in world history but the story of the Trojan War and the Trojan origins of the Franks also are treated as part of the development of the broader historical narrative. The fact that the Trojan ancestry of the Franks is included at great length in Frechulf's Historiae is a clear sign that this origin story continued to be adopted by the Carolingian rulers.

A significant point that stands out from this survey is the ascription of the story of the Trojan origins of the Franks to certain authors. In the Chronicle of Fredegar, the story is found in those sections that are claimed to be excerpts from Jerome's Chronicon and Gregory's Historiae. The story of the Trojan origins in the $L H F$ is not credited to a source but the work itself is attributed to Gregory in the majority of manuscripts. Similarly, the Cosmographia does not attribute the information regarding the Trojan origin of the Franks to any specific authority but then again, the work itself is claimed to be written by Jerome. On the other hand, the $H G F$ keeps the sections about the story of the Trojan origins of the Franks derived from the Chronicle of Fredegar intact, thus, attributing the information once again to Jerome and Gregory. The Chronicon universale utilises both excerpts, from Jerome's Chronicon and Gregory's Historiae, as found in the Chronicle of Fredegar, as well as incorporating information from the $L H F$, yet on both occasions the story is ascribed only to Jerome. The $D e$ origine outright credits Dares of Phrygia as the author in its title. Finally, writing in the early ninth century, Frechulf does not only utilise solely the De origine for the section on the Trojan origins of the Franks but also explicitly presents Dares of Phrygia as the authority on the matter. Thus, by the mid-ninth century, thanks to both Merovingian and Carolingian writers, three auctores, Dares, Jerome and Gregory, none of whom in fact wrote anything about the Trojan origins of the Franks, end up being credited with the story.

The manuscript evidence suggests that those works that were composed in the seventh and eighth centuries that contain the story as well as Frechulf's Historiae circulated extensively in the entire Frankish region throughout the ninth century, thereby indicating that the story of the Trojan origins of the Franks was widely known. ${ }^{\mathrm{I} 22}$ When the dissemination of these manuscripts is considered, it is seen that almost all the major centres across the Frankish region from Tours to Fulda had produced a copy of one or more works that contain the story. Furthermore, even though the survival rate of all of these works seems to be very low, there are even surviving manuscripts of different works produced at the same centres during this period. For example, there are copies of both the Chronicle of Fredegar and the LHF from St Gall, copies of the Chronicle of Fredegar, the $L H F$ and the HGF from Reims and copies of both the Chronicle of Fredegar and Frechulf's Historiae from Reichenau. It may thus easily be claimed

\footnotetext{
${ }^{12}$ Frechulf solely uses the information found in the De origine for the parts that relate the Trojan origins of the Franks even though it seems like he definitely had access to the two other versions found in the Chronicle of Fredegar (and the $H G F$ ) and perhaps even to the $L H F$. One would expect Frechulf to have used the $H G F$ but there are no discernible references to those parts that are only found in the $H G F$ and not in the Chronicle of Fredegar. Yet, to narrate the Trojan origins of the Franks, he used the De origine which is only associated with the $H G F$ in the surviving manuscripts.

${ }^{122}$ Yavuz, 'Transmission and Adaptation': 2I7, provides 38 surviving witnesses dated to the eighth and ninth centuries. These manuscripts were produced in different places across the Frankish region and contain one or more versions of the story.
} 
that, in one version or another, the origin story was known in the entire Frankish region and that the Trojan ancestry of the Franks was an established 'fact' and an integral part of Frankish and Carolingian history by the end of the ninth century.

Another interesting aspect of the story of Trojan origins of the Franks in light of the material evidence is that it is presented within a broader historical context. This is most evident in the seventh-century Chronicle of Fredegar but also in its eighth-century counterpart HGF as well as the Chronicon universale and Frechulf's Historiae. All of these works treat the Trojan narrative as part of the world history. In the Chronicon universale, it is seen that all the passages about Troy in Bede's Chronica are expanded with information from other sources. On the other hand, in the manuscripts of the HGF, one finds Dares of Phrygia's De origine, which provides the story of the fall of Troy in greater detail. Frechulf, similarly, does not only expand on the story of Troy but also writes a seamless history beginning with the creation of the world until his own times. Thus, in these latter cases, the wider Trojan narrative is given an even greater role in conceptions of world history.

This is also true for the $L H F$, despite that it is often commended for its sole focus on

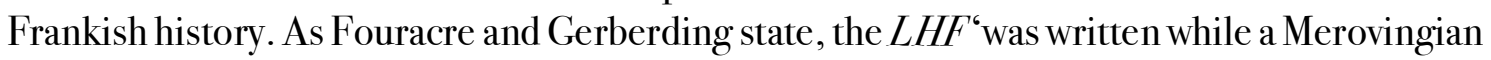
king still ruled over the Franks and by someone geographically very close to the political centre of that realm'. ${ }^{{ }^{22} 3}{ }^{2} 33$ Even though it was a Merovingian production, the $L H F$ widely circulated in Carolingian times. It was not only merely copied but also used as part of larger historical compendia. When the manuscript evidence is examined, it is clear that there are efforts to place the $L H F$ and thereby the history of the Franks and the story of the Trojan origin of the Franks, within a broader historical narrative. In the earliest witness of the $L H F$, Paris, BNF, Lat. 7906 (Part III) + Lat. 50I8 (Part II), the work is preceded by the first five books of Virgil's Aeneid and Dares of Phrygia's De excidio and followed by Bede's Chronicon. ${ }^{124}$ After the portion of the Aeneid that tells about the Trojan War (Books I-V), the text continues to Dares's narration of the history of the fall, and as Dares's text concludes with the Trojans sailing away after the destruction of the city, there begins the $L H F$ which opens with the Trojan origins of the Franks. The compilation also includes Chapter 66 of the De temporum ratione, titled De sex huius mundi aetatibus ['Six Ages of This World'], which provides the broader historical framework. In this compilation, the thematic agenda is further betrayed by the scribe's incipits and explicits. On fol. 8Ir, Dares's Historia concludes with 'explicit gesta Troianorum' ('here ends "The deeds of the Trojans"') and the LHF commences with 'incipit gesta Francorum" ('here begins "The deeds of the Franks") ). This arrangement reflects the common belief that the Franks, like the Romans, traced their lineage back to the Trojans. Indeed, late antique Trojan narratives including Dares's Historia are almost exclusively produced and circulated in the Frankish regions until the twelfth century. ${ }^{\mathrm{I} 25}$

In another manuscript dated to the second third of the ninth century, ${ }^{126}$ the $L H F$ is found together with the anonymous Excidium Troie ['The Destruction of Troy'] and the

\footnotetext{
${ }^{123}$ Fouracre and Gerberding, Late Merovingian France: 79.

${ }^{124}$ For a detailed discussion, see Yavuz, 'Transmission and Adaptation': 2I8-3I.

${ }^{125}$ Yavuz, 'Late Antique Accounts of the Trojan War'.

${ }^{126}$ London, BL, Arundel 375 .
} 
Annales Mettenses priores ['The Earlier Annals of Metz']. ${ }^{127}$ The copy of the Excidium Troie in this compilation is one of the three earliest witnesses of the work, all of which are dated to the ninth century, and the compilation also includes the earliest witness of the Annales Mettenses priores. ${ }^{128}$ Another late antique account, the Excidium Troie, not only tells the story of the destruction of Troy and the migration of the Trojans to Europe but also narrates the foundation of Rome by Aeneas in the form of a summary of Virgil's Aeneid. The Annales Mettenses priores, on the other hand, which immediately follow the Excidium Troie on fol. $72 \mathrm{v}$ in this manuscript, begin with Pippin II 'son of Ansegisel' and narrate the events between 678 and 8o5. As mentioned above, as far as the written evidence survives, Paul the Deacon was the first to connect Ansegisel to Anchises, father of Aeneas, in the 780s. It may be argued that the story was already widespread and thus known by the time the Annales Mettenses priores were composed in c. 805 , if not in fact it was already initiated by the court of Charlemagne. ${ }^{129}$ Thus, in this compilation, too, a similar effect is achieved with that of the Paris manuscript: a history that opens with the Trojan origins of the Franks and that runs from the times of the Trojan War to the times of the Merovingians and then to those of the Carolingians until the beginning of the ninth century.

Another ninth-century manuscript, Vienna, ÖNB, 473, comprises a reworking of the $L H F$ followed and expanded by a portion of the $H G F$, the Annales regni Francorum [known as the 'Royal Frankish Annals'] expanded with an extract from Einhard's Vita Karoli magni ['The Life of Charles the Great'] and a prose genealogy of the Carolingians known as the Domus Carolingicae genealogia ['Genealogy of the Carolingian House']. ${ }^{130}$ The additions by the $H G F$ bring the narrative of the $L H F$ all the way up to the death of Charles Martel in 74I. ${ }^{\mathrm{I} 3^{\mathrm{I}}}$ This is continued with the Annales regni Francorum, which then take up the narrative from the year 74I to $837 .{ }^{132}$ The text of the Annales regni Francorum in this witness is augmented with the insertion of information taken from Einhard's Vita Karoli magni, a biography of Charlemagne possibly completed after his death, between the parts that narrate the reigns of Charlemagne and his son Louis. ${ }^{\mathrm{I} 3}$ The compilation concludes with a short text that details the genealogy of

\footnotetext{
${ }^{127}$ For a detailed discussion, see Yavuz, 'Transmission and Adaptation': $23^{2-38}$. For the editions, see the Excidium Troie and the Annales Mettenses priores, which are both anonymous.

${ }^{128}$ For the manuscripts of the Excidium Troie, see Yavuz, 'Late Antique Accounts of the Trojan War': I6o-64. There might be another early witness to the Excidium Troie, which I have not yet examined. See Terracina, 'Raccontare la Storia'.

${ }^{129}$ The work is thought to be composed under the supervision of (if not directly by) Charlemagne's sister Gisela. See Collins, 'The Frankish Past'; McKitterick, Charlemagne: 6o-65; Hen, 'The Annals of Metz'.

${ }^{130}$ The first part of the codex includes the Liber pontificalis and the Epistola de revelatione sancti Stephani. Even if these two parts were put together at an early stage, palaeographical evidence suggests two different stages of composition. See Collins, Fredegar-Chroniken: 126-28. In Paris, BNF, Lat. IO9II (Part II), the $L H F$, again expanded by borrowings from the $H G F$, is also followed by the Annales regni Francorum, yet the recensions of both works in this manuscript are different from those in Vienna, ÖNB, 473 .

${ }^{13 \mathrm{r}}$ This corresponds to Chapters I-24 of the 'Continuations' of the Chronicle of Fredegar according to the edition.

${ }^{132}$ See the anonymous Annales regni Francorum edited by Kurze.

${ }^{133}$ Einhard, Vita Karoli magni.
} 
the Carolingians as well as listing all the Frankish kings including the Merovingians, which also includes a rewriting of the Trojan origins of the Franks as it is found in the $L H F$. $^{134}$ Furthermore, in this manuscript, a short summary of the Book of Genesis precedes the $L H F$, which in turn continues with no break. The compilation thereby creates a continuous history from the creation of the world with an explicit focus on the history of the Franks, particularly that of the Carolingians. Thus, the compilation as a whole almost achieves the same effect as a seamless world history with an emphasis on the Franks, such as the Chronicon universale. ${ }^{135}$ In short, not only the longer historical texts discussed here but also these manuscript compilations bear witness that the story of the Trojan origins of the Franks was considered as part of the larger Trojano-Frankish history and also that the Frankish history was seen in the context of the broader history of the world.

Originating in their Gallo-Roman heritage, the story of the Trojan origins of the Franks was first promoted during the reign of the Merovingians but was also very much welcomed by the Carolingians. There was a continued appropriation of the story despite changes in political power. It may even be argued that following the extraordinary engagement with the story of the Trojan origins of the Franks in the eighth century as well as its association with Charlemagne himself, the Carolingian period saw the beginning of consolidation of ideas about the descent of the Franks. In the later centuries, not only the Capetians, rulers of the Frankish world after the Carolingians, but also different houses of Europe tied themselves to the Trojans by putting Charlemagne at centre stage and making him an important Trojano-Frankish figure with his lineage tied all the way back to Priam, the king of the Trojans-and the first king of the Franks. ${ }^{136}$ Gruen states that 'the embrace of Troy [...] enabled Rome to associate itself with the rich and complex fabric of Hellenic tradition, thus to enter that wider cultural world, just as it had entered the wider political world'. ${ }^{137}$ Centuries later the Franks did just the same for similar reasons, but instead of associating themselves with the Romans, they went back to the source, to the Trojans, in a manner of imitatio imperï, in order first to claim a piece of the Romanitas and eventually replace it altogether with Frankishness.

\footnotetext{
${ }^{134}$ Domus Carolingicae genealogia. See also Genealogiae Karolorum: 245.

${ }^{135}$ The manuscript Vienna, ÖNB, 473 has been the subject of many studies. See especially Reimitz, 'Ein karolingisches Geschichtsbuch'; McKitterick, 'Political Ideology': I62-74; McKitterick, History and Memory: especially I2I-23 and 2I5-I6; Collins, Fredegar-Chroniken: I23-24.

${ }^{136}$ See, for example, Ademar of Chabannes, Chronicon. See also Godfrey of Viterbo, Speculum regum, which promoted the Hohenstaufen family, discussed in Latowsky, Emperor of the World: 202-05. ${ }^{137}$ Gruen, Culture and National Identity: 3.
} 


\section{Abbreviations}

BAV Biblioteca Apostolica Vaticana

BL British Library

BNF Bibliothèque nationale de France

BSGRT Bibliotheca Scriptorum Graecorum et Romanorum Teubneriana

CCCM Corpus Christianorum. Continuatio Mediaevalis

CCSL Corpus Christianorum. Series Latina

HGF Historia vel gesta Francorum

LCL Loeb Classical Library

LHF Liber historiae Francorum

MGH AA Monumenta Germaniae Historica. Auctores antiquissimi

MGH PL Monumenta Germaniae Historica. Poetae Latini medii aevi

MGH SRG Monumenta Germaniae Historica. Scriptores rerum Germanicum in usum scholarum separatim editi

MGH SRLI Monumenta Germaniae Historica. Scriptores rerum Langobardicarum et Italicarum

MGH SRM Monumenta Germaniae Historica. Scriptores rerum Merovingicarum

MGH SS Monumenta Germaniae Historica. Scriptores in folio

MGH ST Monumenta Germaniae Historica. Studien und Texte

UBL Universiteitsbibliotheek Leiden

TRW The Transformation of the Roman World

\section{Declaration of Conflicting Interests}

The author declared no potential conflicts of interest with respect to the research, authorship and/or publication of this article.

\section{Funding}

This study has received funding from the European Union's Horizon 2020 Research and Innovation Programme under the Marie Sk.odowska-Curie grant agreement no. $70277^{2}$. 


\section{References}

Ademar of Chabannes. 1999. Ademari Cabannensis Chronicon, edited by Pascale Bourgain, Georges Pon, and Richard Allen Landes, CCCM, ז29. Turnhout: Brepols.

Ammianus Marcellinus. 1935-1940. History. Translated by John C. Rolfe, LCL, 3OO, 3I5, 33I, 3 vols. London: Heinemann.

Annales Mettenses priores. I905. Edited by Bernhard von Simson, MGH SRG, IO. Hanover: Hahn.

Annales regni Francorum. 1895. Annales regni Francorum inde ab a. 741 usque ad a. 829, qui dicuntur Annales Laurissenses maiores et Einhardi, edited by Friedrich Kurze, MGH SRG, 6. Hanover: Hahn.

Anton, Hans Hubert. 20oo. 'Troja-Herkunft, origo gentis und frühe Verfaßtheit der Franken in der gallisch-fränkischen Tradition des 5. bis 8. Jahrhunderts', Mitteilungen des Institutsfür Österreichische Geschichtsforschung, vol. Io8: I-30.

Asher, R.E. 1993. 'The Idea of a Trojan Origin', in his National Myths in Renaissance France: Francus, Samothes and the Druids. Edinburgh: Edinburgh University Press: 9-43.

Badian, Ernst. 2009. 'From the Iulii to Caesar', in A Companion to Julius Caesar, edited by Miriam Griffin. Malden, MA: Wiley-Blackwell: II-22.

Barlow, Jonathan. 1995. 'Gregory of Tour sand the Myth of the Trojan Origins of the Franks', Frühmittelalterliche Studien, vol. 29: 86-95.

Bede the Venerable. 1977. 'De temporum ratione', in Opera Didascalica, edited by C. W. Jones, C. B. Kendall, M. H. King, and F. Lipp, vol. 2, CCSL, I23B. Turnhout: Brepols: $263-544$.

---. I999. The Reckoning of Time. Translated by Faith Wallis. Translated Texts for Historians, 29. Liverpool: Liverpool University Press.

Bouchard, Constance B. 2006. 'Images of the Merovingians and Carolingians', History Compass, vol. 4: 293-307.

Chronicon universale. I88I. Chronicon universale - 741, cum continuatione (Annalibus Maximinianis), edited by Georg Waitz, MGH SS, I3. Hanover: Hahn: I-25.

Claszen, David. 2012. Chronicon Moissiacense Maius: A Carolingian World Chronicle from Creation until the First Years of Louis the Pious. On the Basis of the Manuscript of the Late Ir. J. M. J. G. Kats. 2 vols. Unpublished Master's Thesis: Department of History, University of Leiden, Leiden.

Collins, Roger. I996. Fredegar. Authors of the Middle Ages, 4.I3. Aldershot: Variorum.

---. 2002. 'The Frankish Past and Carolingian Present in the Age of Charlemagne', in Am Vorabend der Kaiserkrönung: Das Epos 'Karolus Magnus et Leo papa' und der Papstbesuch in Paderborn 799, edited by Peter Godman, Jörg Jarnut, and Peter Johanek. Berlin: Akademie Verlag: 3OI-22.

---. 2007. Die Fredegar-Chroniken. MGH ST, 44. Hanover: Hahn.

Cornell, T.J. 1995. The Beginnings of Rome: Italy and Rome from the Bronze Age to the Punic Wars (c. 1000-264 BC). London: Routledge.

Cornford, Benjamin. 20o6. 'Paul the Deacon's Understanding of Identity, His Attitude to Barbarians, and His "Strategies of Distinction" in the Historia Romana', in Texts and Identities in the Early Middle Ages, edited by Richard Corradini, Rob Meens, Christina 
Pössel, and Philip Shaw. Vienna: Verlag der Österreichischen Akademie der Wissenschaften: $47-60$.

Darby, Peter. 2012. Bede and the End of Time. Farnham: Ashgate.

Dares of Phrygia. I873. Daretis Phrygï de excidio Troiae historia, edited by Ferdinand Meister, BSGRT. Leipzig: Teubner.

---. I874. 'Historia Daretis Frigï de origine Francorum, [edited by] Gaston Paris', Romania, vol. 3: 129-44.

---. I888. 'Historia Daretis Frigï de origine Francorum', in Fredegarï et aliorum chronica. Vitae sanctorum, edited by Bruno Krusch, MGH SRM, 2. Hanover: Hahn: 194-200.

--_. I966. 'The Fall of Troy: A History by Dares the Phrygian', in The Trojan War: The Chronicles of Dictys of Crete and Dares the Phrygian, translated by Richard M. Frazer, Jr. Bloomington: Indiana University Press: I3I-68.

Domus Carolingicae genealogia. I829. In Scriptores. Tomus II, edited by Georg Heinrich Pertz, MGH SS, 2. Hanover: Hahn: 3o8-12.

Dumville, David. 2002. 'What Is a Chronicle?', in The Medieval Chronicle II: Proceedings of the and International Conference on the Medieval Chronicle, Driebergen/Utrecht, 1621 July 1999, edited by Erik Kooper, Costerus New Series, I44. Amsterdam: Rodopi: I27.

Einhard. г9I. Einhardi Vita Karoli magni, edited by Oswald Holder-Egger, MGH SRG, 25. Hanover: Hahn.

Eutropius. I879. Eutropi Breviarium ab urbe condita cum versionibus Graecis et Pauli Landolfique additamentis, edited by Hans Droysen, MGH AA, 2. Berlin: Weidmann.

Ewig, Eugen. 1997. 'Le Mythe troyen et l'histoire des Francs', in Clovis histoire \& mémoire: Clovis et son temps, l'événement, edited by Michel Rouche. Paris: Presses de l'Université de Paris-Sorbonne: 8I7-47.

Excidium Troie. 1986. Edited by Alan Keith Bate, Lateinische Sprache und Literatur des Mittelalters, 23. Frankfurt am Main: Peter Lang.

Faral, Edmond. r969. 'Comment s'est formée la légende de l'origine troyenne des Francs', in his La Légende arthurienne: études et documents. Première partie: les plus anciens textes, 3 vols. Paris: Honoré Champion: vol. I: 262-93 (First pub. 1929).

Fouracre, Paul, and Richard A. Gerberding. 1996. Late Merovingian France: History and Hagiography, 640-720. Manchester: Manchester University Press.

Frechulf of Lisieux. 2002. 'Historiarum libri XIT, in Frechulfi Lexoviensis episcopi opera omnia, edited by Michael I. Allen, vol. 2, CCCM, I69A. Turnhout: Brepols: 9-724.

Fredegar. I888. 'Chronicarum quae dicuntur Fredegarii Scholastici libri IV. cum Continuationibus', in Fredegariiet aliorum chronica. Vitae sanctorum, edited by Bruno Krusch, MGH SRM, 2. Hanover: Hahn: I-I93.

---. 196o. The Fourth Book of the Chronicle of Fredegar and Its Continuations, edited and translated by John Michael Wallace-Hadrill. London: Nelson.

Garipzanov, Ildar H. 2005. 'The Carolingian Abbreviation of Bede's World Chronicle and Carolingian Imperial "Genealogy", Hortus Artium Medievalium, vol. II: 29I-98.

Garrison, Mary. 200o. 'The Franks as the New Israel? Education for an Identity from Pippin to Charlemagne', in The Uses of the Past in the Early Middle Ages, edited by Yitzhak Hen and Matthew Innes. Cambridge: Cambridge University Press: I75-90. 
Geary, Patrick J. 1983. 'Ethnicity as a Situational Construct in the Early Middle Ages', Mitteilungen der anthropologischen Gesellschaft in Wien, vol. II3: I5-26.

Genealogiae Karolorum. I88ı. Edited by Georg Waitz, MGH SS, I3. Hanover: Hahn: 242-48. Gerberding, Richard A. 1987. The Rise of the Carolingians and the Liber Historiae Francorum'. Oxford: Clarendon Press.

Ghosh, Shami. 20I5. Writing the Barbarian Past: Studies in Early Medieval Historical Narrative. Brill's Series on the Early Middle Ages, 24. Leiden: Brill.

Godfrey of Viterbo. I872. 'Speculum regum', in Scriptores. Tomus XXII, edited by Georg Pertz, MGH SS, 22. Hanover: Hahn: 2I-93.

Goffart, Walter. 1963. 'The Fredegar Problem Reconsidered', Speculum, vol. 38: 206-41.

--_. I986. 'Paul the Deacon's Gesta Episcoporum Mettensium and the Early Design of Charlemagne's Succession', Traditio, vol. 42: 59-94.

---. 1988. The Narrators of Barbarian History (A.D. 550-80o): Jordanes, Gregory of Tours,

Bede, and Paul the Deacon. Princeton, NJ: Princeton University Press.

Gregory of Tours. 1937-I95. Gregorï Turonensis opera: Libri historiarum X, edited by Bruno Krusch and Wilhelm Levison, MGH SRM, I.I. Hanover: Hahn.

---. 1974. The History of the Franks. Translated by Lewis Thorpe. Harmondsworth: Penguin. Gruen, Erich S. 1992. Culture and National Identity in Republican Rome. Cornell Studies in Classical Philology, 52. Ithaca, NY: Cornell University Press.

Hen, Yitzhak. 200o. 'The Annals of Metz and the Merovingian Past', in The Uses of the Past in the Early Middle Ages, edited by Yitzhak Hen and Matthew Innes. Cambridge: Cambridge University Press: I75-90.

Herren, Michael W. 200I. 'The "Greek Element” in the Cosmography of Aethicus Ister', The Journal of Medieval Latin, vol. II: I85-20I.

-- . 2004. 'The "Cosmography" of Aethicus Ister. Speculations About Its Date, Provenance, and Audience', in Nova de veteribus. Mittel- und neulateinische Studien für Paul Gerhard Schmidt, edited by Andreas Bihrer and Elisabeth Stein. Munich: K. G. Saur: 79-IO2.

--_. 20IIa. 'The Cosmography of Aethicus Ister: One More LatinNovel?', in Fictional Traces: Receptions of the Ancient Novel, edited by Marília P. Futre Pinheiro and Stephen J. Harrison, Ancient Narrative. Supplementum, I4.I, vol. I. Groningen: Barkhuis Publishing and Groningen University Library: $33^{-54}$.

---. 20IIb. 'Introduction', in The Cosmography of Aethicus Ister, edited and translated by Michael W. Herren. Turnhout: Brepols: i-cxix.

Hibernicus Exul. I88ı. 'Hibernici Exulis et Bernowini carmina', in Poetae Latini aevi Carolini (I), edited by Ernst Dümmler, MGH PL, I. Berlin: Weidmann: 393-425.

Hydatius. 1993. The 'Chronicle' of Hydatius and the 'Consularia Constantinopolitana': Two Contemporary Accounts of the Final Years of the Roman Empire, edited and translated by Richard W. Burgess. Oxford: Clarendon Press.

Innes, Matthew. 200o. 'Teutons or Trojans? The Carolingians and the Germanic Past', in The Uses of the Past in the Early Middle Ages, edited by Yitzhak Hen and Matthew Innes. Cambridge: Cambridge University Press: 227-49.

Isidore of Seville. I9II. Etymologiarum sive originum: libri $X X$. Edited by W. M. Lindsay. 2 vols. Oxford: Clarendon Press. 
-—-. 2003. Isidori Hispalensis Chronica. Edited by José Carlos Martín. CCSL, II2. Turnhout: Brepols.

---. 2006. The Etymologies of Isidore of Seville. Translated by Stephen A. Barney and others. Cambridge: Cambridge University Press.

James, Edward. 1998. 'Gregory of Tours and the Franks', in After Rome's Fall: Narrators and Sources of Early Medieval History; Essays Presented to Walter Goffart, edited by Alexander Callander Murray. Toronto: University of Toronto Press: 5 ${ }^{\mathrm{I}-66 .}$

St. Jerome. 1956. Eusebius Caesariensis. Werke. 7: Die Chronik des Hieronymus / Hieronymi Chronicon, edited by Rudolf Helm. Diegriechischen christlichen Schriftsteller der ersten Jahrhunderte, 47. Berlin: Walter de Gruyter.

(Ps.) St. Jerome. r9I9-I920. 'Origo Francorum duplex: Aethici Istri cosmographi et codicis Bonnensis legis Salicae', in Passiones vitaeque sanctorum aevi Merovingici (V), edited by Bruno Krusch and Wilhelm Levison, MGH SRM, 7. Hanover: Hahn: 517-28.

---. 2OII. The Cosmography of Aethicus Ister, edited and translated by Michael W. Herren. Turnhout: Brepols.

John the Lydian. I983. On Powers, Or the Magistracies of the Roman State: Introduction, Critical Text, Translation, Commentary, and Indices, edited and translated by Anastasius C. Bandy, Memoirs of the American Philosophical Society, I49. Philadelphia: The American Philosophical Society.

Jones, Charles W. 1976. 'Bede's Place in Medieval Schools', in Famulus Christi: Essays in Commemoration of the Thirteenth Centenary of the Birth of the Venerable Bede, edited by Gerald Bonner. London: S.P.C.K.: 26I-85.

Jung, Marc-René. 1997. 'L'historie grecque: Darès et les suites', in Entre fiction et histoire: Troie et Rome au moyen âge, edited by Emmanuèle Baumgartner and Laurence HarfLancner. Paris: Presses de la Sorbonne Nouvelle: I85-206.

Kempf, Damien. 2004. 'Paul the Deacon's Liber de episcopis Mettensibus and the Role of Metz in the Carolingian Realm', Journal of Medieval History, vol. 30: 279-99.

---. 20I3. 'Introduction', in Paul the Deacon, Liber de episcopis Mettensibus, edited and translated by Damien Kempf, Dallas Medieval Texts and Translations, i9. Leuven: Peeters: I-39.

Krusch, Bruno. I882a. 'Die Chronicae des sogenannten Fredegar', Neues Archiv der Gesellschaft für ältere deutsche Geschichtskunde, vol. 7: 247-35'.

-_-. I882b. 'Die Chronicae des sogenannten Fredegar II', Neues Archiv der Gesellschaft für ältere deutsche Geschichtskunde, vol. 7: 42I-516.

Kurze, Friedrich. I9oo. 'Die Karolingischen Annalen des achten Jahrhunderts', Neues Archiv der Gesellschaft für ältere deutsche Geschichtskunde, vol. 25: 29I-3I5.

Laistner, Max L.W. 1943. A Hand-List of Bede Manuscripts. Ithaca, NY: Cornell University Press.

Lapidge, Michael. 2008. 'Beda Venerabilis', in La Trasmissione dei Testi Latini del Medioevo /MedievalLatin Texts and Their Transmission. Te.Tra., vol. 3, edited by Paolo Chiesa and Lucia Castaldi, Millennio medievale, 75, Strumenti e studi. Nuova serie, I8. Florence: SISMEL - Edizioni del Galluzo: 44-I37.

Latowsky, Anne A. 20I3. Emperor of the World: Charlemagne and the Construction of Imperial Authority, 80o-1229. Ithaca, NY: Cornell University Press. 
Law, Vivian. I994. 'The Study of Grammar', in Carolingian Culture: Emulation and Innovation, edited by Rosamond McKitterick. Cambridge: Cambridge University Press: 88-107.

Liber historiae Francorum. I888. In Fredegarï et aliorum chronica. Vitae sanctorum, edited by Bruno Krusch, MGH SRM, 2. Hanover: Hahn: 2I5-328.

-_-.I973. Edited and translated by Bernard S. Bachrach. Lawrence, KA: Coronado Press.

Livy. I9I9-I959. History of Rome. Translated by B. O. Foster et al. LCL, II4, I33, I72, I9I, 223 , 355, 367, 381, 295, 301, 313, 332, 396, 404. I4 vols. London: Heinemann.

Luiselli, Bruno. 1978. 'Il mito dell'origine troiana dei Galli, dei Franchi e degli Scandinavi', Romanobarbarica, vol. 3: 89-I2I.

Manitius, Max. г9го. 'Zur karolingischen Literatur', Neues Archiv der Gesellschaft für ältere deutsche Geschichtskunde, vol. 36: 4I-75.

McCormick, Michael. 1986. Eternal Victory: Triumphal Rulership in Late Antiquity, Byzantium, and the Early Medieval West. Cambridge: Cambridge University Press.

McKitterick, Rosamond. I980. 'Charles the Bald (823-877) and His Library: The Patronage of Learning', The English Historical Review, vol. 95: 28-47.

---. 1983. The Frankish Kingdoms under the Carolingians, 751-987. London: Longman.

---. 1994. 'Women and Literacy in the Early Middle Ages', in her Books, Scribes, and Learning in the Frankish Kingdoms, 6th-gth Centuries, Variorum Collected Studies Series, 452. Aldershot: Ashgate: I-43.

---. 200o. 'Political Ideology in Carolingian Historiography', in The Uses of the Past in the Early Middle Ages, edited by Yitzhak Hen and Matthew Innes. Cambridge: Cambridge University Press: I62-74.

---. 2004. History and Memory in the Carolingian World. Cambridge: Cambridge University Press.

---. 2008. Charlemagne: The Formation of a European Identity. Cambridge: Cambridge University Press.

Murray, Alexander Callander. 1998. 'Post Vocantur Merohingi: Fredegar, Merovech, and "Sacral Kingship", in After Rome's Fall: Narrators and Sources of Early Medieval History. Essays Presented to Walter Goffart, edited by Alexander Callander Murray.

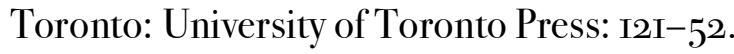

Murray, Alexander Callander (ed. and trans.). 20oo. From Roman to Merovingian Gaul: A Reader. Readings in Medieval Civilizations and Cultures, 5. Toronto: Broadview Press.

Nelson, Janet L. I996. 'Gender and Genre in Women Historians of the Early Middle Ages', in her The Frankish World, 750-9oo. London: Hambledon Press: I83-97.

Paul the Deacon. I878. 'Pauli historia Langobardorum', in Scriptores rerum Langobardicarum et Italicarum. Saec. VI-IX, edited by Ludwig Bethmann and Georg Waitz, MGH SRLI, I. Hanover: Hahn: I2-I807.

-_-. 19I4. Pauli Diaconi Historia Romana, edited by Amadeo Crivellucci, Fonti per la Storia d'Italia, 5r. Rome: Tipografia del Senato.

--_. 2003. History of the Lombards, edited by Edward Peters, translated by William Dudley Foulke. Philadelphia: University of Pennsylvania Press (First pub. 1907). 
--_. 20I3. Liber de episcopis Mettensibus, edited and translated by Damien Kempf, Dallas Medieval Texts and Translations, I9. Leuven: Peeters.

Perret, Jacques. 1942. Les Origines de la légende Troyenne de Rome (281-31).Paris: Société d'édition 'Les Belles lettres'.

Pohl, Walter. 1998. 'Conceptions of Ethnicity in Early Medieval Studies', in Debating the Middle Ages: Issues and Readings, edited by Lester K. Little and Barbara H. Rosenwein. Oxford: Blackwell: $\mathrm{I5}^{-24}$.

---. Forthcoming. 'Historiography and Identity-Methodological Perspectives', in Historiography and Identity 1: Ancient and Early Christian Narratives of Community, edited by Walter Pohl and Veronika Wieser. Turnhout: Brepols.

Poucet, Jacques. 1985. Les Origines de Rome: tradition et histoire. Publications des facultés universitaires Saint-Louis, 38. Brussels: Facultés universitaires Saint-Louis.

Priscian. I855. Prisciani Institvtionvm grammaticarvm libri I-XII. Edited by Martin Hertz, in Grammatici Latini, vol II, edited by Heinrich Keil. Leipzig: Teubner.

Reimitz, Helmut. 2000. 'Ein karolingisches Geschichtsbuch aus Saint-Amand: Der Codex Vindobonensis palat. 473', in Text-Schrift - Codex: Quellenkundliche Arbeiten aus dem Institut für Österreichische Geschichtsforschung, edited by Christoph Egger and Herwig Weigl, Mitteilungen des Instituts für Österreichische Geschichtsforschung. Ergänzungsband, 35. Vienna: R. Oldenbourg: 34-9o.

---. 20I5. History, Frankish Identity and the Framing of Western Ethnicity, 550-850. Cambridge Studies in Medieval Life and Thought, Fourth Series, IoI. Cambridge: Cambridge University Press.

Rose, Charles Brian. 20I4. The Archaeology of Greek and Roman Troy. Cambridge: Cambridge University Press.

Sage, Michael. 2000. 'Roman Visitors to Ilium in the Roman Imperial and Late Antique

Period: The Symbolic Functions of a Landscape', Studia Troica, vol. IO: 2II-3I.

Sallust. 20I3. The War with Catiline, The War with Jugurtha. Translated by John C. Rolfe. LCL, II6. Rev. edn. Cambridge, MA: Harvard University Press.

Scholl, Christian. 20I7. 'Imitatio Imperiu? Elements of Imperial Rule in the Barbarian Successor States of the Roman West', in Transcultural Approaches to the Concept of Imperial Rule in the Middle Ages, edited by Christian Scholl, Torben R. Gebhardt, and Jan Clauß. Frankfurt: Lang: 19-39.

Smaragdus of Saint-Mihiel. I986. Liber in partibus Donati, edited by Bengt Löfstedt, Louis Holtz, and Adele Kibre, CCCM, 68. Turnhout: Brepols.

Terracina, Alessandra. 20I2. 'Raccontare la Storia: un manoscritto poco conosciuto dei Chronica Maiora di Beda il Venerabile', Pecia: Le livre et l'écrit, vol. I4: 243-65.

Virgil. 20o9. Aeneis. Edited by Gian Biagio Conte. BSGRT. Berlin: Walter de Gruyter.

Wallace-Hadrill, John Michael. I958. 'Fredegar and the History of France', Bulletin of the John Rylands Library, vol. 40: 527-50.

---. 1960. 'Introduction', in The Fourth Book of the Chronicle of Fredegar with Its Continuations, edited and translated by John Michael Wallace-Hadrill. London: Nelson: ix-lxvii.

Weinstock, Stefan. I97. Divus Julius. Oxford: Clarendon Press. 
Wolfram, Herwig. I994. 'Origo et Religio: Ethnic Traditions and Literature in Early Medieval Texts', Early Medieval Europe, vol. 3: 19-38.

Wood, Ian N. I994. The Merovingian Kingdoms, 450-751. London: Longman.

---. 1995. 'Defining the Franks: Frankish Origins in Early Medieval Historiography', in Concepts of National Identity in the Middle Ages, edited by Simon Forde, Lesley Johnson, and Alan V. Murray, Leeds Texts and Monographs New Series, I4. Leeds: University of Leeds: $47-57$.

---. 1999. 'The Use and Abuse of Latin Hagiography in the Early Medieval West', in East and West: Modes of Communication: Proceedings of the First Plenary Conference at Merida, edited by Evangelos Chrysos and Ian N. Wood, TRW, 5. Leiden: Brill: 93IIO.

---. 2000. 'Aethicus Ister: An Exercise in Difference', in Grenze und Differenz im frühen Mittelalter, edited by Walter Pohl and Helmut Reimitz, Philosophisch-Historische Klasse Denkschriften, 287 , Forschungen zur Geschichte des Mittelalters, I. Vienna: Verlag der österreichischen Akademie der Wissenschaften: I97-208.

---. 2002. 'Teutsind, Witlaic and the History of Merovingian precaria', in Property and Power in the Early Middle Ages, edited by Wendy Davies and Paul Fouracre. Cambridge: Cambridge University Press: $3^{\mathrm{I}-5^{2}}$.

-_- 2003. 'Deconstructing the Merovingian Family', in The Construction of Communities in the Early Middle Ages: Texts, Resources and Artefacts, edited by Richard Corradini, Max Diesenberger, and Helmut Reimitz, TRW, I2. Leiden: Brill: I49-7I.

--_. 20I5. 'Universal Chronicles in the Early Medieval West', Medieval Worlds, vol. I: 4760.

Yavuz, N. Kıvılcım. 20I5. Transmission and Adaptation of the Trojan Narrative in Frankish History between the Sixth and Tenth Centuries. Unpublished PhD Thesis: Institute for Medieval Studies, University of Leeds, Leeds.

--_. 20I6. 'Late Antique Accounts of the Trojan War: A Comparative Look at the Manuscript Evidence', Pecia: Le livre et l'écrit, vol. I7: I49-70.

--_. 20I7. 'Looking Back at the Fifth Century: Revisiting the Origin of the Franks'. Unpublished paper: Shifting Frontiers in Late Antiquity XII, Yale University, New Haven, CT, USA. 